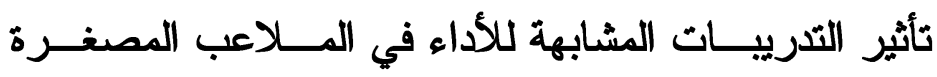
على سرعه اتخاذ القرار الخططي لناشئي كرة القدم

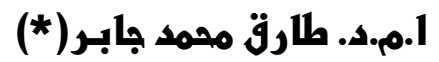

المقدمة ومشكلة البحث : الإد

الأداء المهارى في كرة القدم مجموعة من الأداءات الحركية الفرديسـة

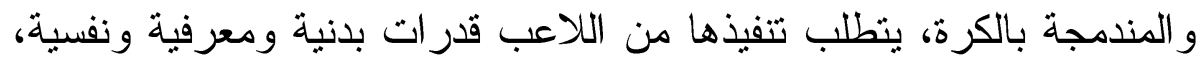

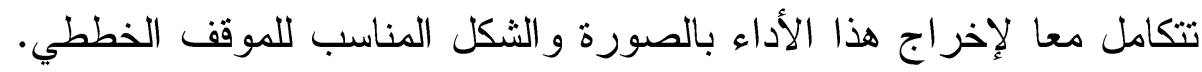

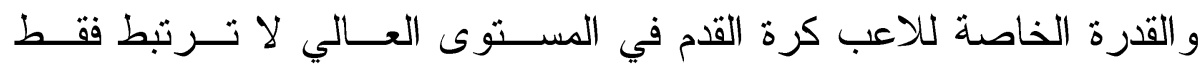

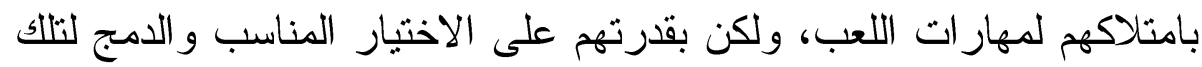

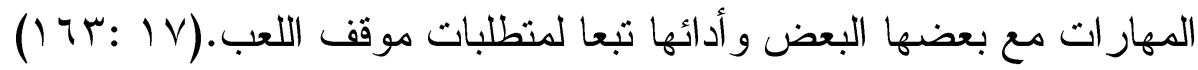

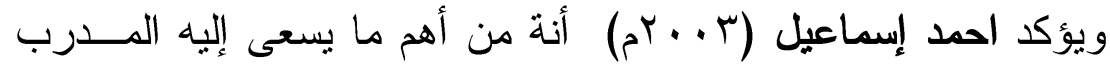

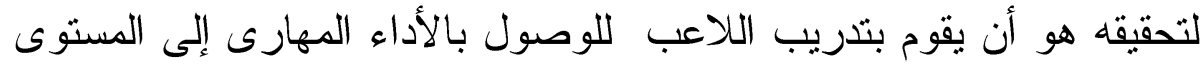

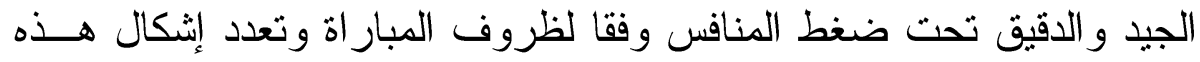

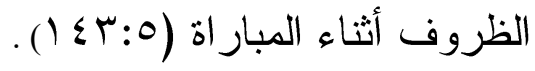

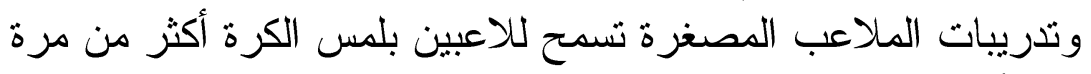

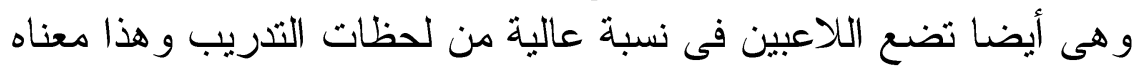

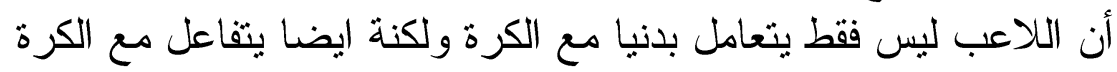

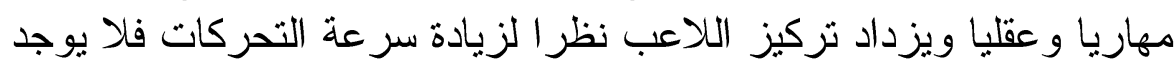

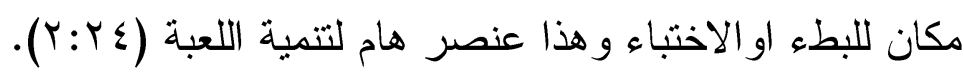

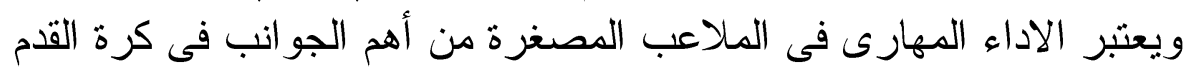

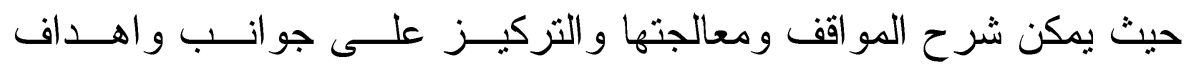

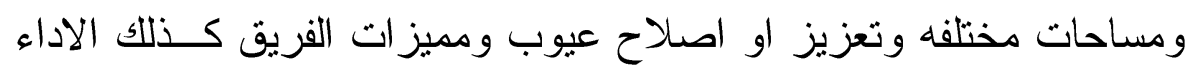
الفردى و الجماعى للفريق.

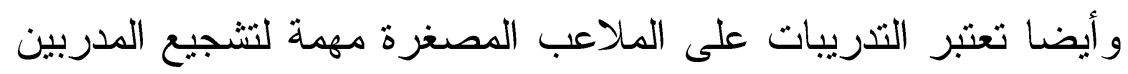

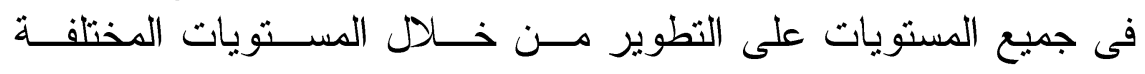

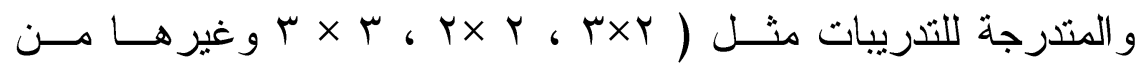

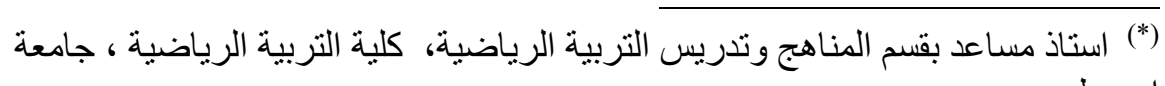


التشكيلات ) و أيضا من مميزات الملاعب المصــغرة فـرص الســــاح

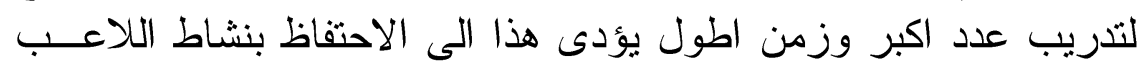

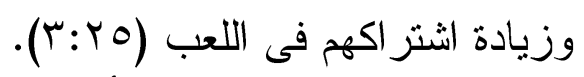

يرى مفتى إبر اهيم ( •99 1) أنه يمكن تقسيم الملعب و هميا الى تقديمات

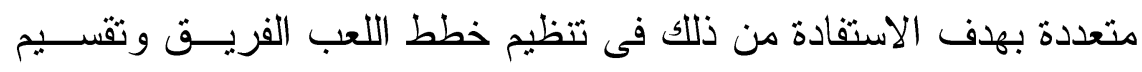

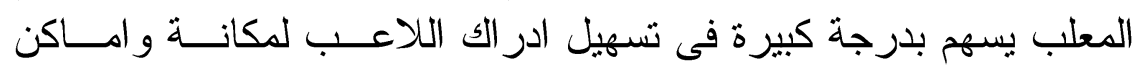

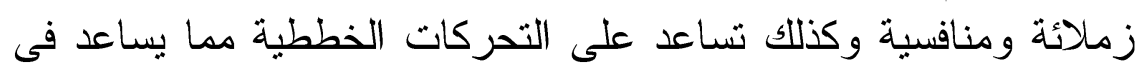

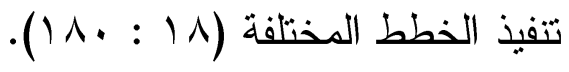

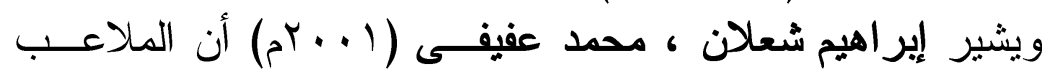

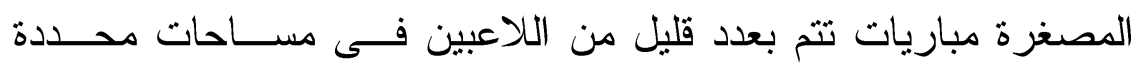

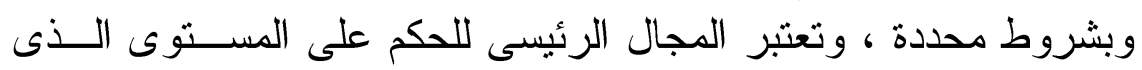

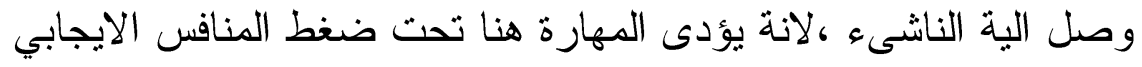

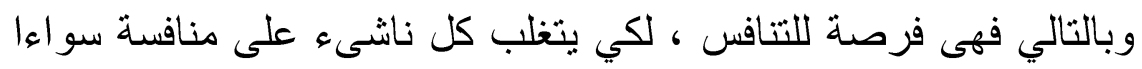
بطريقة فردية ابتداء من اللعب (X) (X) او بطريقة جماعية (ع:19) (19) .

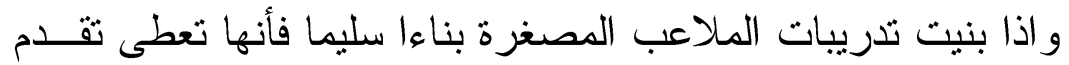

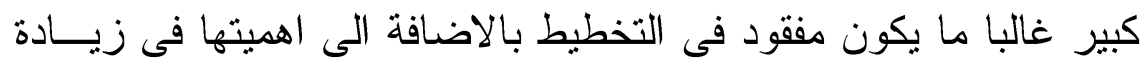

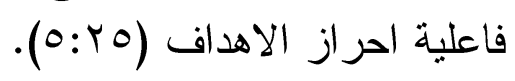

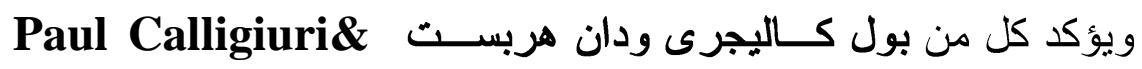
(99V) Dancers

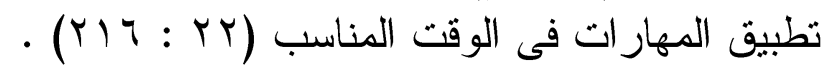

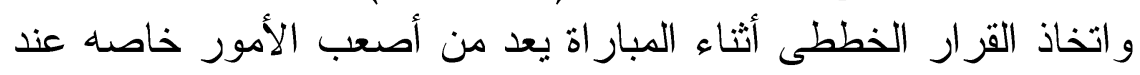

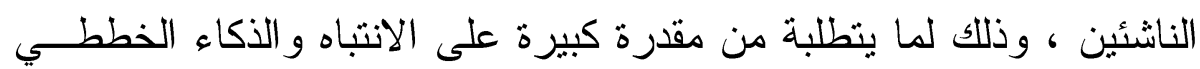

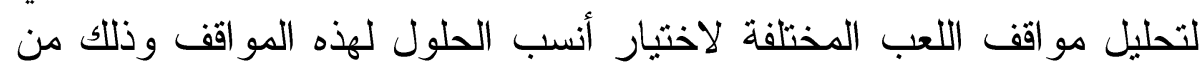
خلال ملاحظة زملاءه و المنافسين.

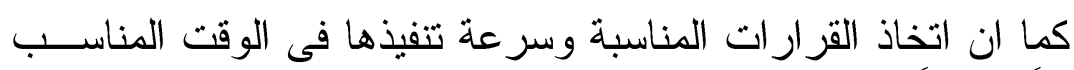

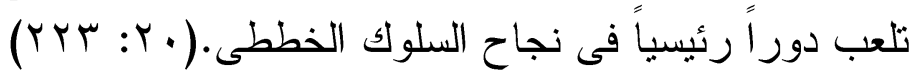

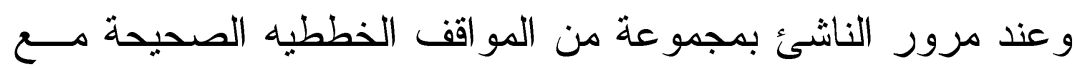

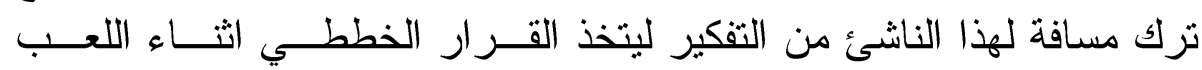




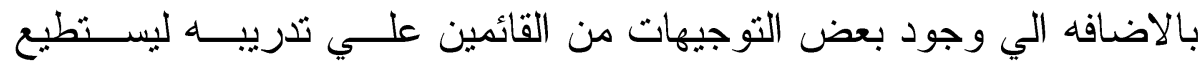

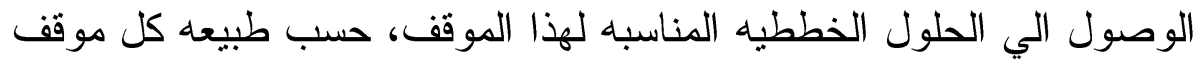
علي حده، يتم تخزين هذه المواقف وحلولها المثاليه التي تم تتفيذها بالفعل في لونه ذاكره الناشئ، مما يوفر لديه كم لا حصر لله من المواقف الخططيه وحلولها

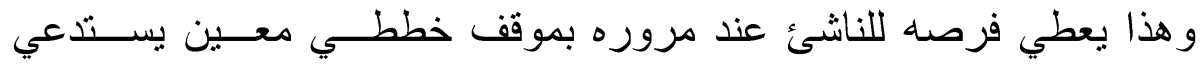

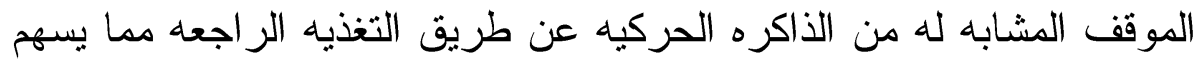

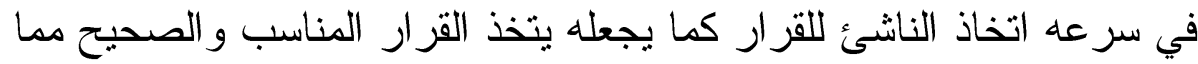
يسهم في توفير وقته وجهده ويعود علي الفريق بافضل النتائج التي تحقق له له

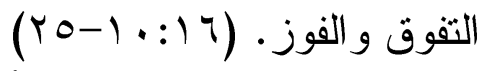

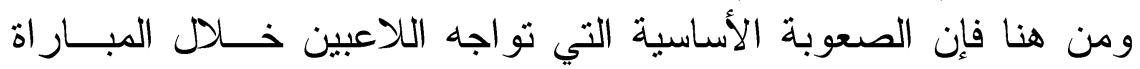

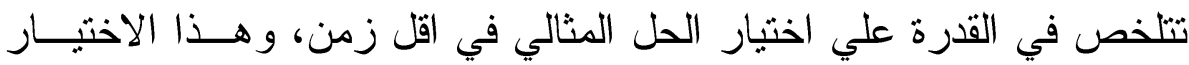

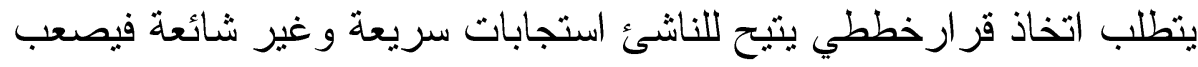

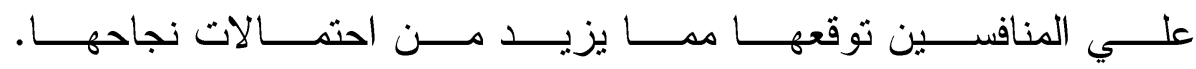

(1:10)

كما أن التدريبات فى المساحات المختلفة تؤدى إلى تتمية وتطوير

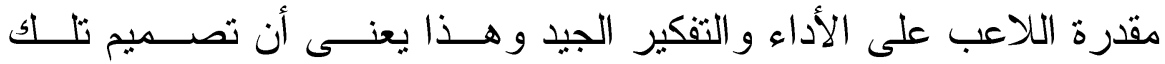

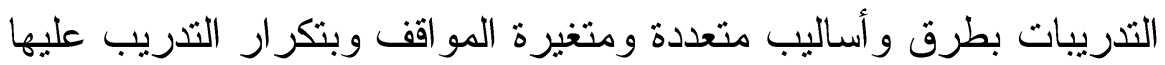

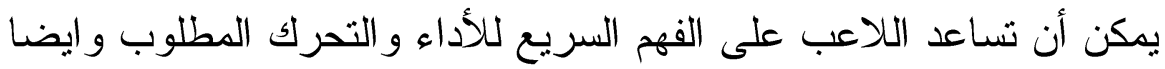

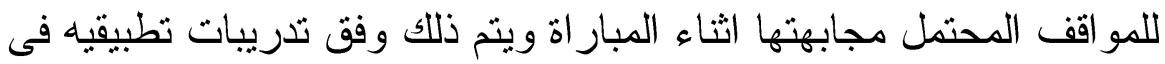

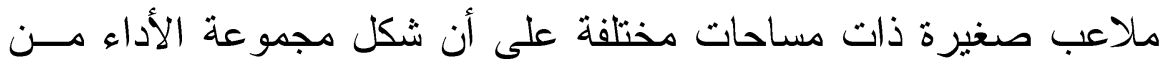

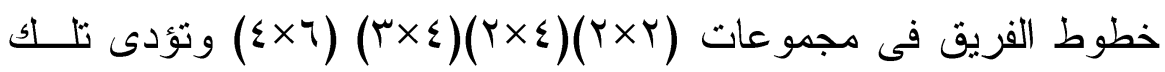

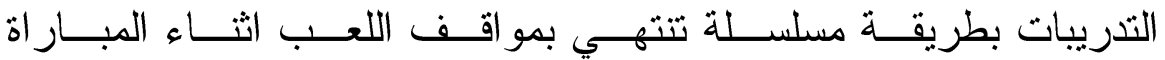

$$
\text { . (Y } 96 \text { \% } 1: 11)
$$

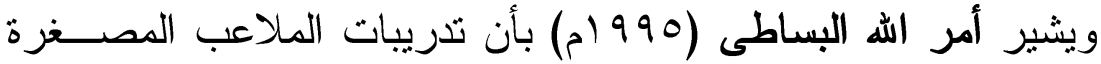

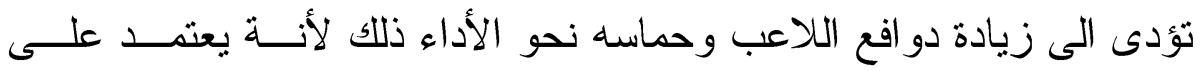

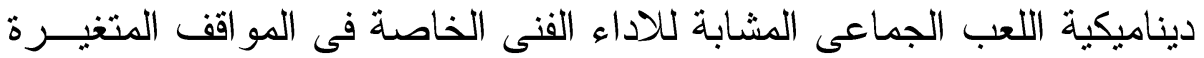

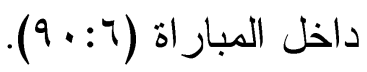


ويذكر" محمد بلال (999 (199) بأن تغيير المساحة بالنسبة للملعب و الشكل

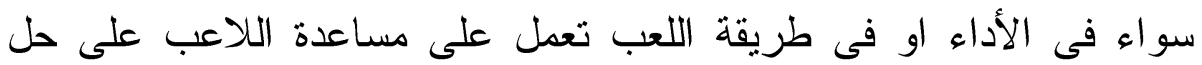

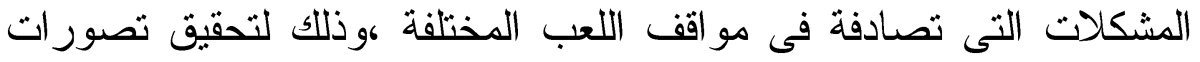

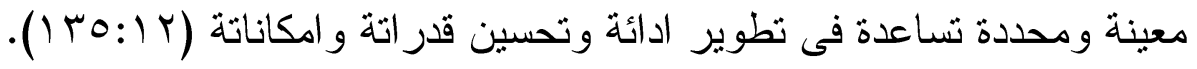
و اتخاذ القرار Decision Making عملية المفاضلة بين الحلول البديلة و المتاحة، و اختيار أكثر هذه الحلول صلاحية لتحقيق الهدف من حل المشكلة. (Or -01:1)

واتخاذ القرارهو عملية مفاضلة بين البدائل المتاحة، لاختيار أفضل بديل، للوصول إلى الهدف. ويتم ذلك عن طريق تحديد الهدف أو المشكلة، ثم تحديد

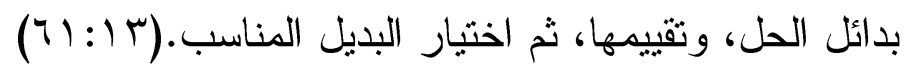

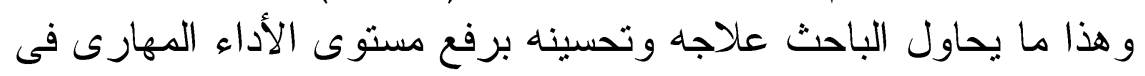

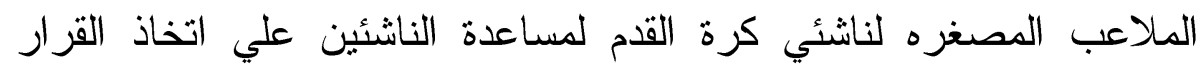
الخططى الصحيح. هدف البحث:-

يهدف البحث الى التعرف على تأثير استخدام التذريبات المشابهه للاداء فى الملاعب المصغرة على سرعه اتخاذ القرار الخططى لناشئى كرة القدم. فروض البحث:-

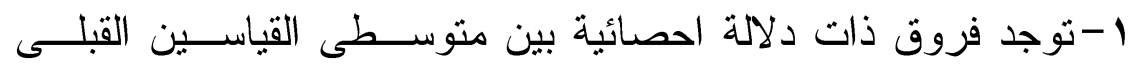

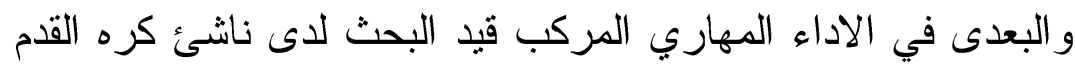
لصالح القياس البعدى.

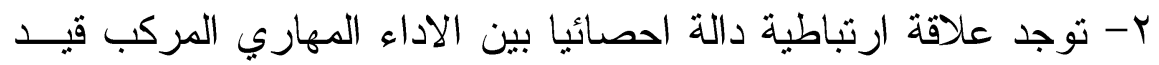

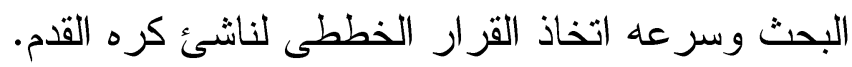

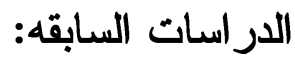

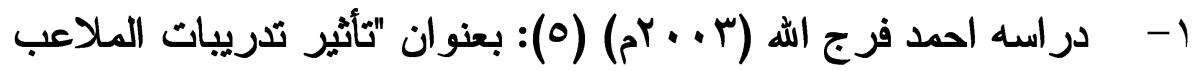

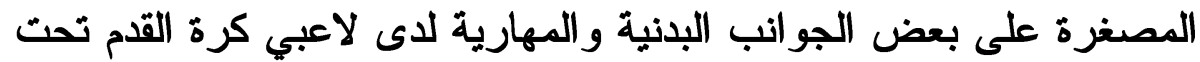

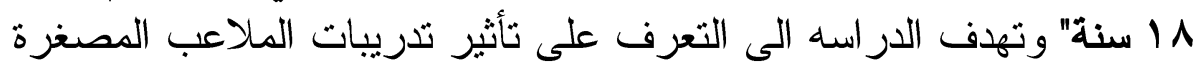

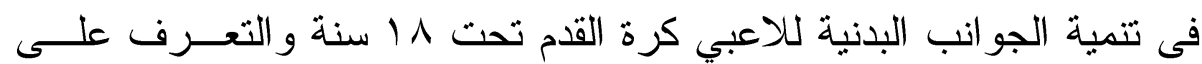


تأثير التثريب على الملاعب المصغرة فى تنمية الجوانب المهارية للاعبـي

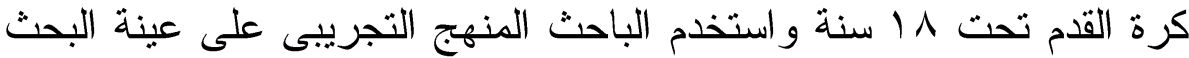

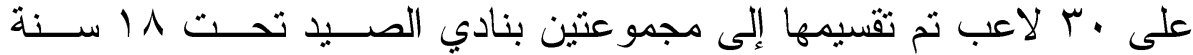

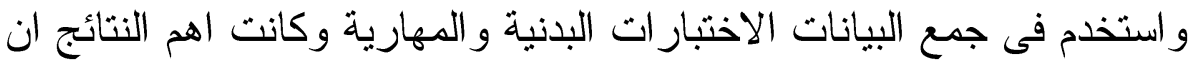

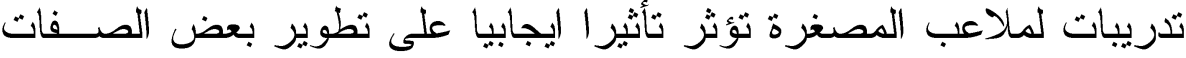

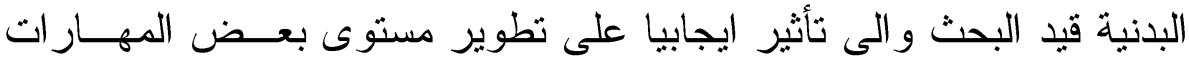
المهارية الأساسية قيد البحث.

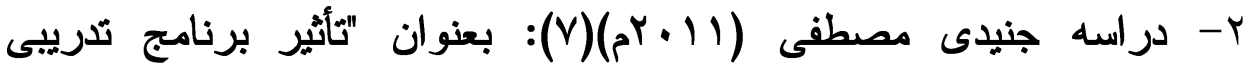

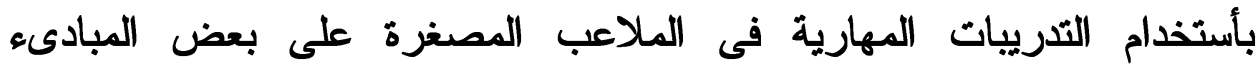

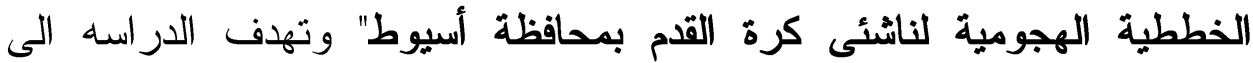

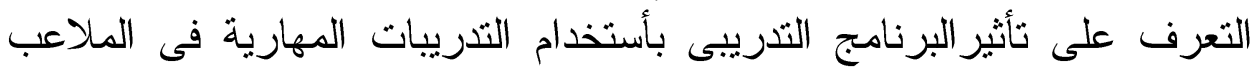
المصغرة على بعض المبادىء الخططية الهجومية لناشئى كرة القدم بمحافظة

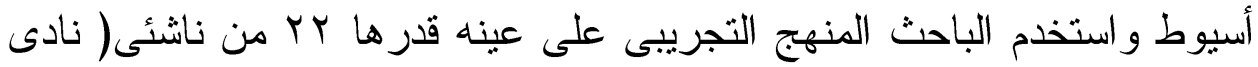

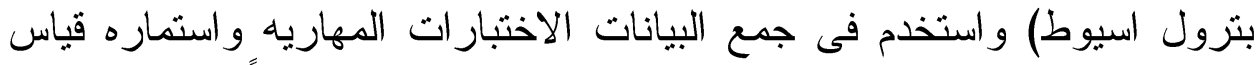
المبادىء الخططيه وكانت اهم النتائج وجود فروق دالة إحصائيا بين متوسطات

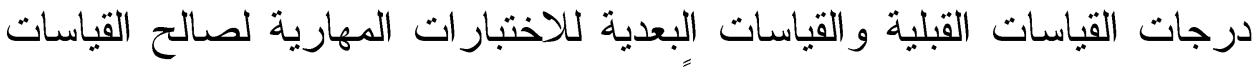
البعدية وجود فروق دالة إحصائياً بين متوسطات درجات القياسات القبلية و القياسات البعدية (للمبادئ الخططية الهجومبة) لصالح القية القياسات البعدية

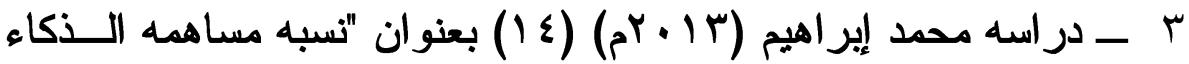

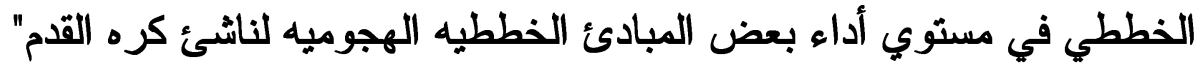

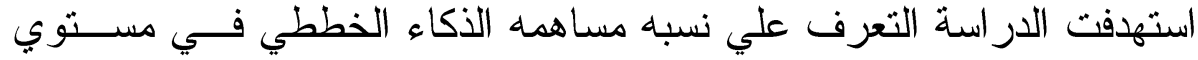

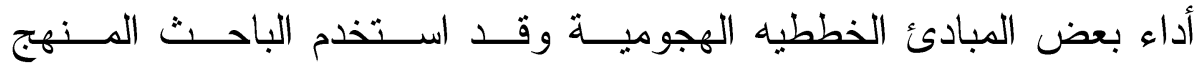

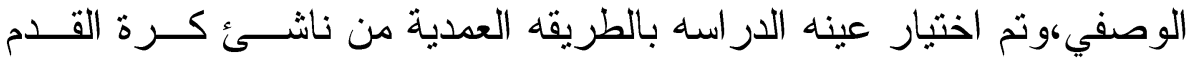

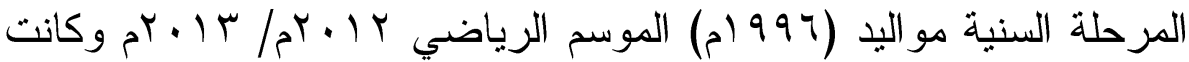

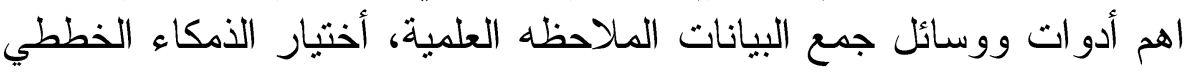

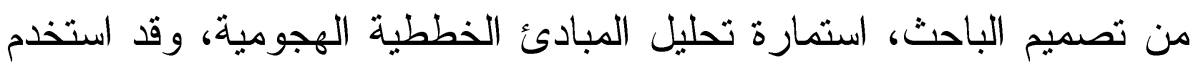
أسلوب التحليل الاحصائي (التحليل المنطقي للانحدار) وكان من اهم النتئ النـائج

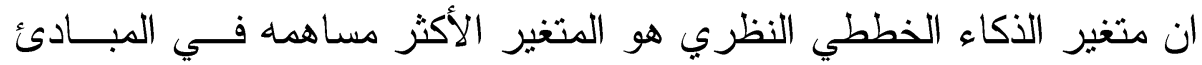




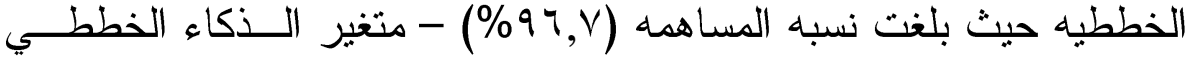

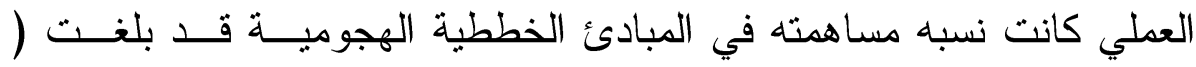
. $(\% 00,7$

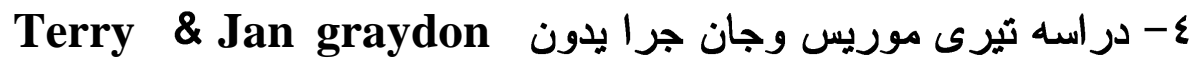
Morris

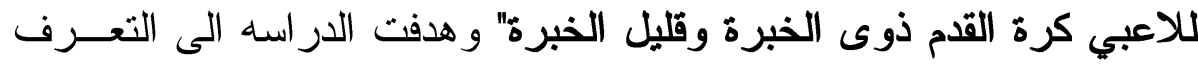

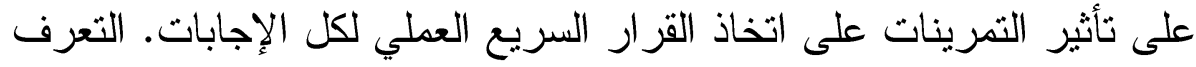

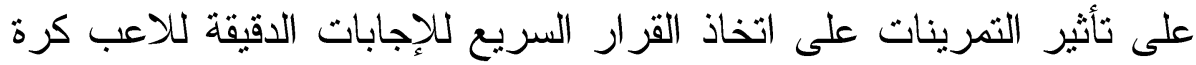

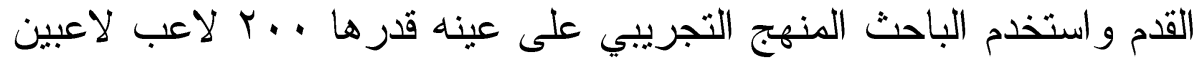

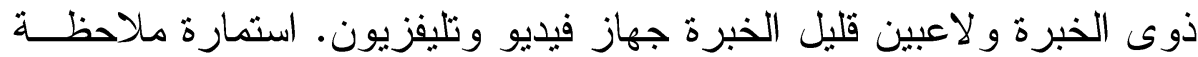

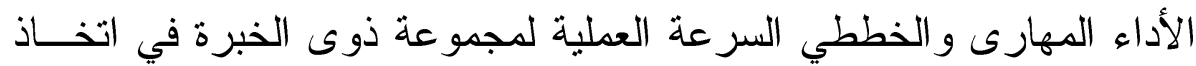

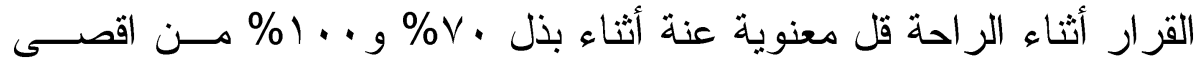

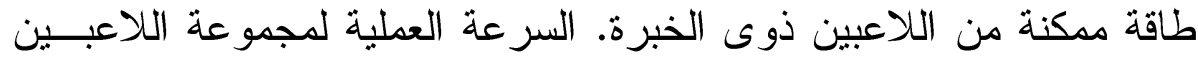

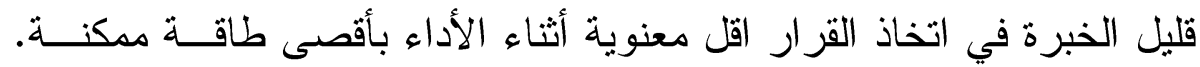

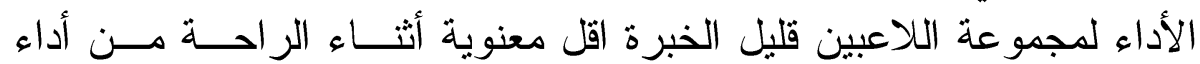
اللاعبين ذوى الخبرة في كلتا مستويين التدريب.

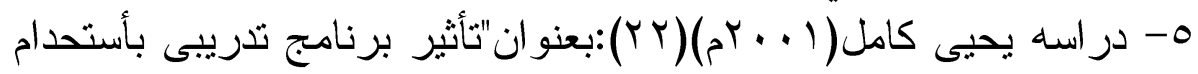

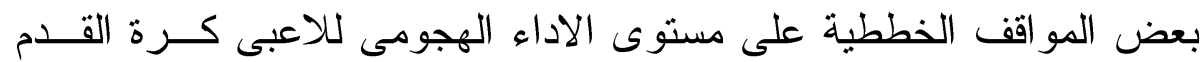

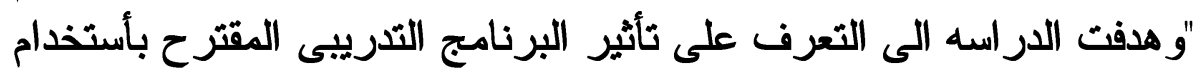

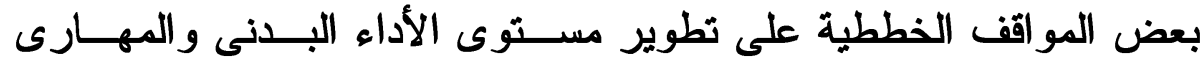

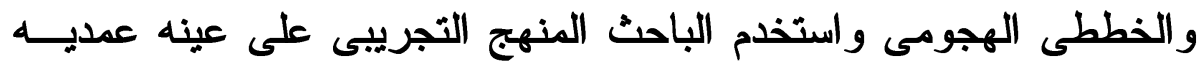

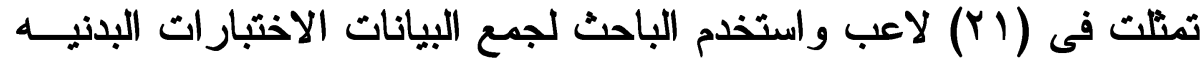

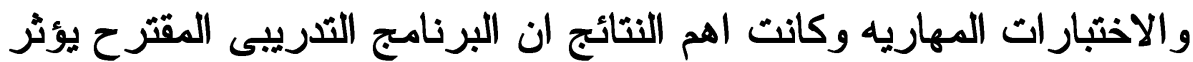

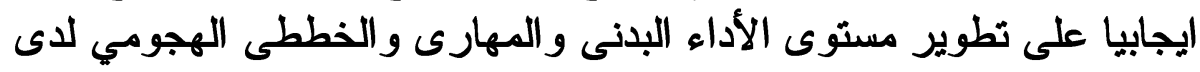

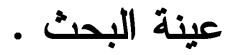


خطه واجراءات البحث:

منهج البحث: واجث:

استخدم الباحث المنهج التجريبي من خلال استخدام "التصميم التجريبي للمجموعة الو احدة عن طريث القياس القبلي و البعدي " وذلك لمناسبته لطبيعة

يشمل مجتمع البحث لاعبي كره القدم من الناشئين موالبد 991 ام

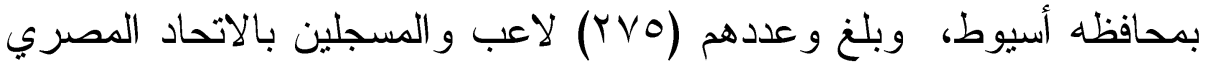

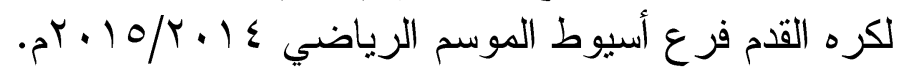
عينه البحث:

قام الباحث باختيار عينة البحث بطريقة عمدية من ناشئ كره القدم

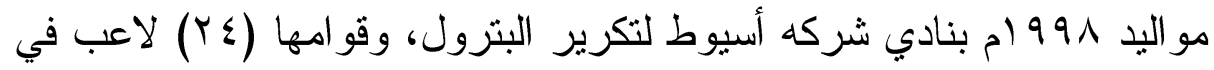

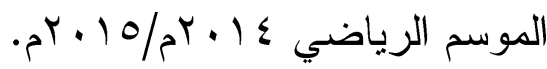

تجانس أفر اد عينه البحث :

قام الباحث بإيجاد المتوسط الحسابي والئ الاندر اف المعياري ودعامل

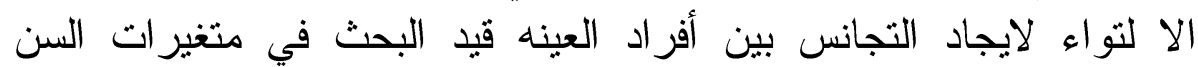
و الطول و الوزن و العمر التدريبى، و الجدول (1) يوضح ذلك. للك.

جدول (1)

تجانس افراد العينة قيد البحث (بد = ع

\begin{tabular}{|c|c|c|c|c|}
\hline معامل الالتواء & $\varepsilon^{ \pm}$ & س & وحدة القياس & المتفيرات \\
\hline .1. & Y.00 & 187.11 & شهر & السن \\
\hline.$\leqslant 0$ & r.71 & 10人.r. & سم & الطول \\
\hline..$v$ & r.o. & $01.7 Y$ & كجم & الوزن \\
\hline 1.11 &..$\leqslant 7$ & $1 . Y \varepsilon$ & سنة & العمر التذريبي \\
\hline
\end{tabular}

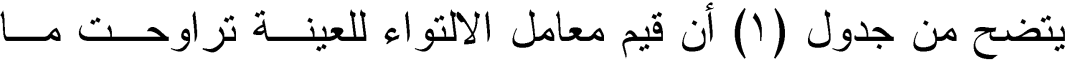

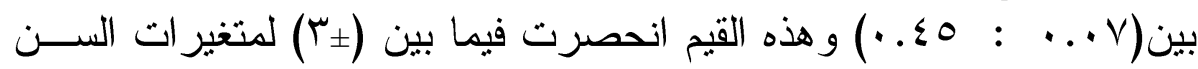


و الطول و الوزن و العمر التدريبي وهذا يؤكد تجانس أفر اد العينة قيد البحـــ في تلك المتغير ات.

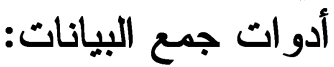
تحليل المراجع والأبحاث العمية: البية:

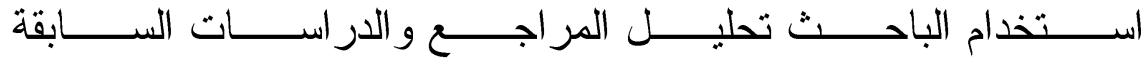

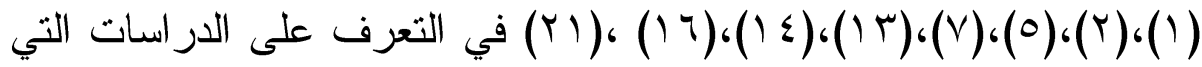

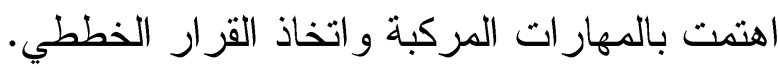
الملاحظة العلمية:

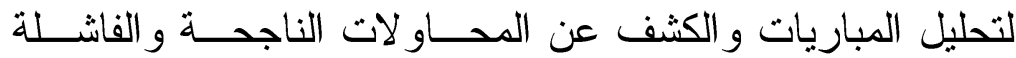
لاتخاذ القرار الخططي باستخدام المساعدات التالية: أ - جهاز تسجيل مرئي ثلاثي النظام مزود بنظام العرض البطيء التهي و السريع

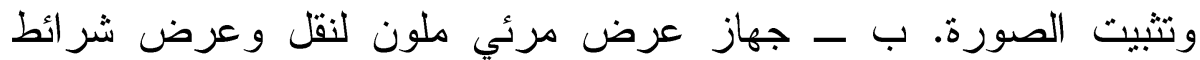

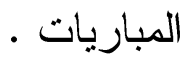

\section{المقابلة الشخصبة:}

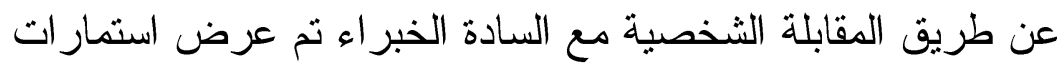
الاستبيان كل على حده لإبداء الرأي و عددهم (^) خبر اء، مرفق (1) (1).

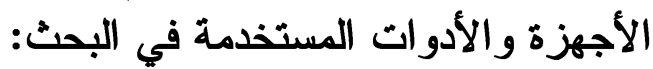

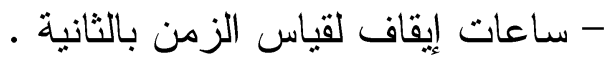

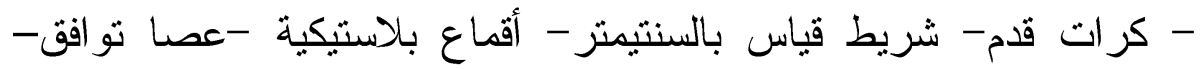

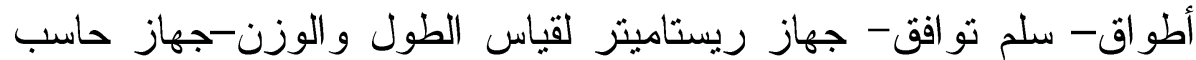

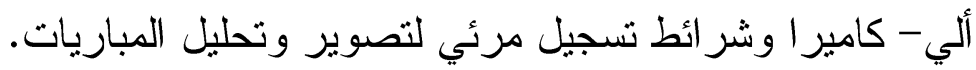

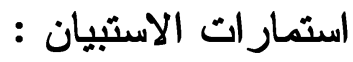
قام الباحث بثصميم واستخدام الاستمار الات التالية:

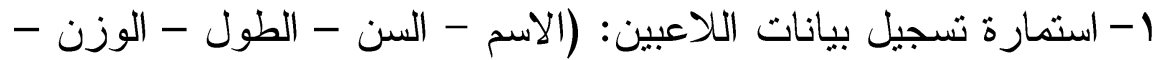
العمر التدريبي)، مرفق( (ب).

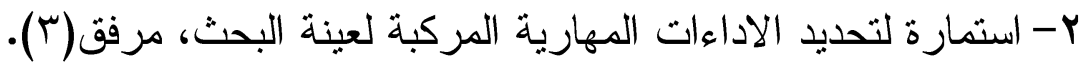

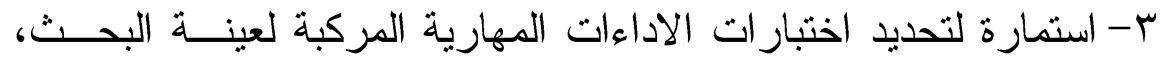

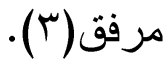


ع- التدريبات المهاريه فى الملاعب المصغره المستخدمه فــى البرنــامج.

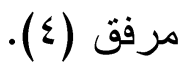

0- استمارة لقياس القرار الخططي الناجح و الفاشل ، مرفق (0). اختبارات الاداءات المهارية المركبة:

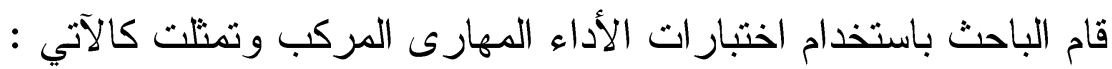

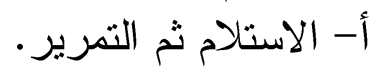

ب- الاستلام ثم الجري بالكرة ثم التمرير •

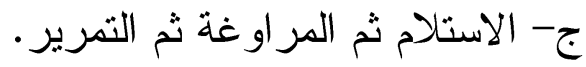

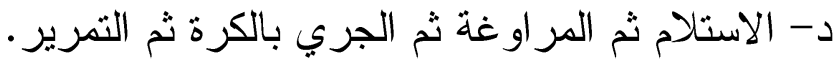

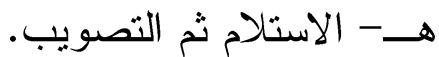

استمارة اتخاذ القرارث الخططية:

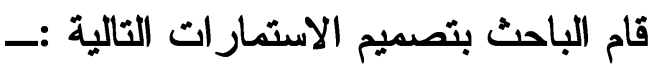

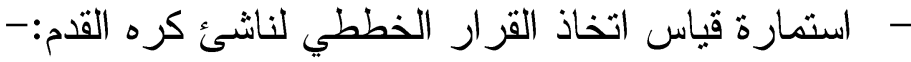

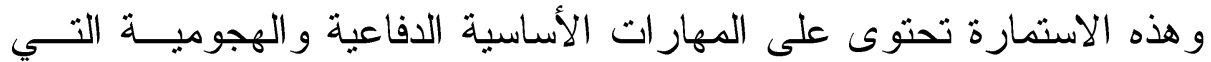

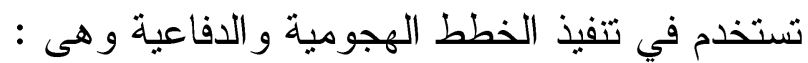
وسائل تنفيذ الخطط الهجومية (الفردية - الجماعية):

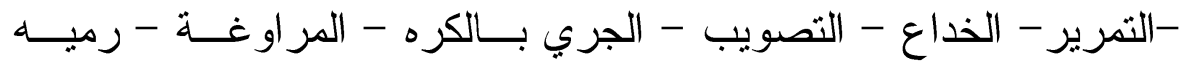
التماس

وسائل ثنفيذ الخطط الدفاعية (الفردي - الجماعية): - الضغط - الخداع - التغطية - التشتيث - التهاعيه - المهاجمة. - و هذه الاستمارة تحتوي علي القرار الخططي الناجح و القرار الخططي الفاشل لكل وسيله من الوسائل السابقة. - بعد تصوير المباريات قيد البحث تم حصر القرار ات التي اتخذت سواء دفاعية أو هجومية.

- تم عرض الاستمارة مرفق (ع) علي السادة الخبراء للتعديل أو الإضافة حتى وصلت لصورتها النهائية.

الخطو ات التنفيذية : أن

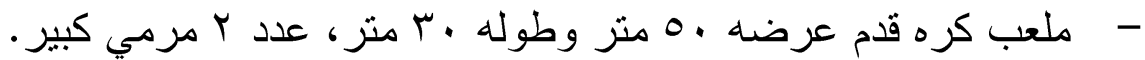


- تقسيم عينه البحث إلي ع مجموعات كل مجموعه 7 ناشئين.

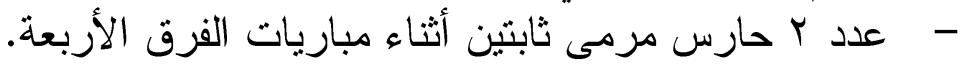

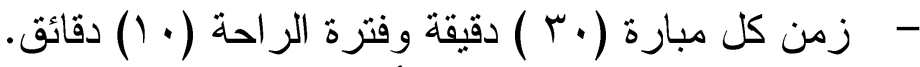

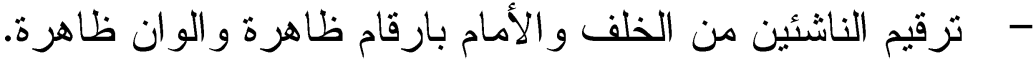

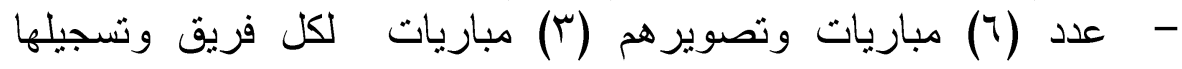
و ونقاه على الثرائط فيديو . - تحليل المباريات ال(آ) لحصر واستخرج كل القرارات الخططيه الدفاعيه و الهجومبه الفرديه والجماعيه التي اتخذها الناشئين في المباريات

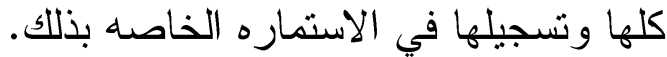
المعاملات العلمية للإختبار ات المستخدمة الإنيات (الصدق - الثباته):

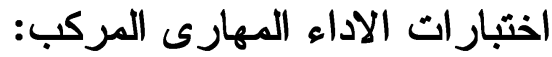

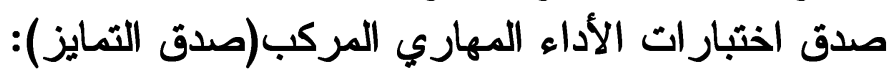

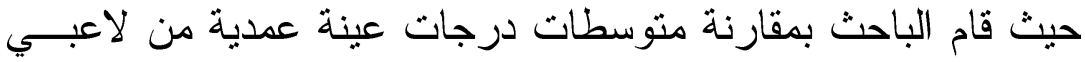

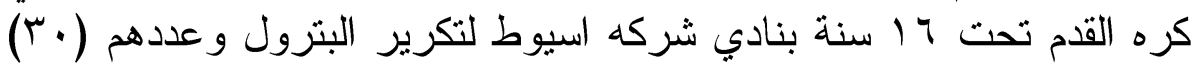

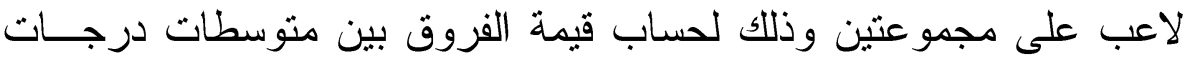

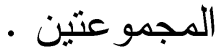

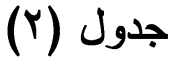

دلالة الفروق بين متوسطات القياسات لأفراد المجمو عتين المميزة وغير

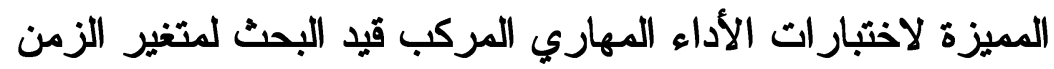
( $10=r=10)$

\begin{tabular}{|c|c|c|c|c|c|c|c|}
\hline | قيمة ت & \multicolumn{2}{|c|}{ تصت 17 العينة المميزة $17=$} & \multicolumn{2}{|c|}{ تعتبنة العير الميزة } & \multirow[t]{2}{*}{ : } & \multirow[t]{2}{*}{ الاختبـــار ات } & \multirow[t]{2}{*}{ r } \\
\hline & $\varepsilon^{ \pm}$ & 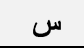 & $\varepsilon^{ \pm}$ & 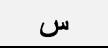 & & & \\
\hline $\begin{array}{r}1.090 \\
*\end{array}$ &.$\leqslant 1$ & 0.74 &.$r \varepsilon$ & $\leqslant . \wedge T$ & ث & الاستلام ثم التمرير • & 1 \\
\hline $\begin{array}{r}V . M T \leq \\
*\end{array}$ & r. & $\checkmark . \leqslant r$ &.$\varepsilon$. & T.VY & $\ddot{\Xi}$ & الاستلام ثم الجري بالكره ثم التمرير . & $\begin{array}{r} \\
\end{array}$ \\
\hline $\begin{array}{r}\Lambda .99 Y \\
*\end{array}$ & ro & A.v) & 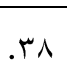 & V.9Y & $\ddot{\Xi}$ & الاستلام ثم المراوغة ثم التمرير & r \\
\hline $\begin{array}{r}7 . r \cdot 9 \\
*\end{array}$ & . & $\begin{array}{ll}11.1 \\
v\end{array}$ & .01 & $11.1 \mathrm{r}$ & 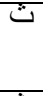 & والتمرير الاستلام ثم المراوغة ثـــم الجـري بـــالكره & $\varepsilon$ \\
\hline$V_{.} \cdot V_{T}$ & ra & S.rY & 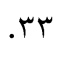 & $r .7 \wedge$ & 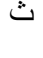 & 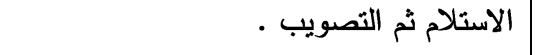 & 0 \\
\hline
\end{tabular}




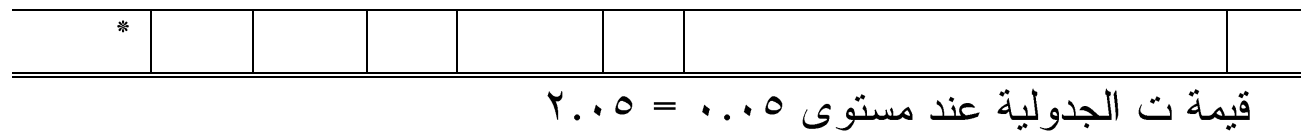

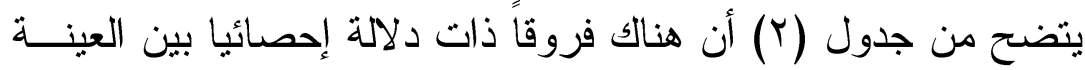

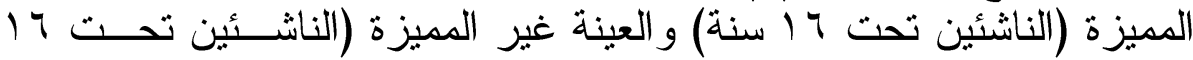

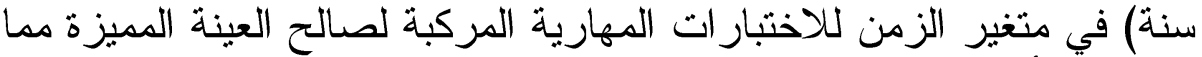
يدل على أن الاختبار ات قادرة على التمييز بين ناشئي كره القدم تحــــ 17

\section{جدول (r) (إساب)}

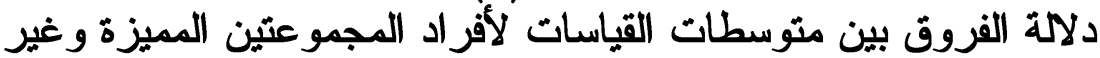

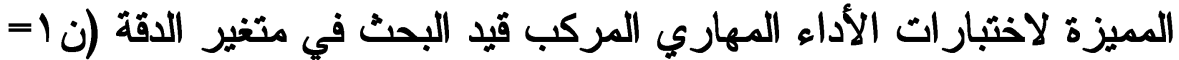

\begin{tabular}{|c|c|c|c|c|c|c|c|}
\hline \multirow[t]{2}{*}{ المحسو تبة } & \multicolumn{2}{|c|}{ تحتب العينة المميزة } & \multicolumn{2}{|c|}{ تحيتة غيز المميزة 17 (10 } & \multirow{2}{*}{$\begin{array}{l}1 \\
1 \\
: 0 \\
\frac{7}{3}\end{array}$} & \multirow[t]{2}{*}{ الاختبــــار ات } & \multirow[t]{2}{*}{ s } \\
\hline & $\varepsilon^{ \pm}$ & س & $\varepsilon^{ \pm}$ & س & & & \\
\hline$* 0 . \vee r q$ & 每 & r.IT & $.0 Y$ & T.EV & درجة & الاستلام ثم التمرير • & 1 \\
\hline$* 0 . V \mu q$ & .10 & r... &.$\leqslant 9$ & س"r. & درجة & |الاستلام ثم الجري بالكره ثم التمرير . & r \\
\hline$* 4.1 \leq 1$ &.$\vee \wedge$ & r.r. & $.0 Y$ & r.sV & درجة & الاستلام ثم المر اوغة ثم التمرير & r \\
\hline *V.ITo & r & r.IT & $.0 Y$ & $r \leq V$ & 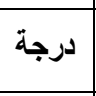 & 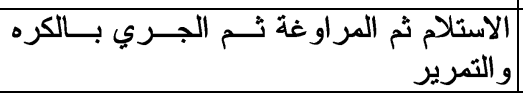 & $\varepsilon$ \\
\hline$* 0.7 . r$ & $.9 r$ & $1 . \wedge \mathrm{V}$ & .0 & r.s. & درجة & 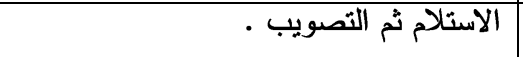 & 0 \\
\hline
\end{tabular}

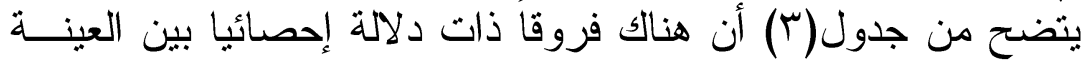

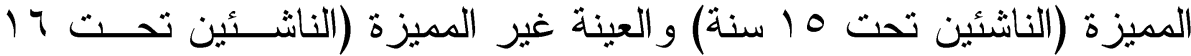

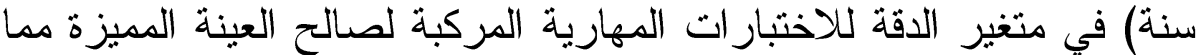

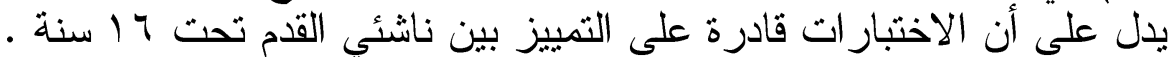

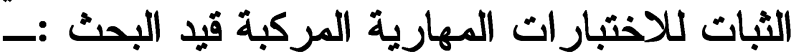

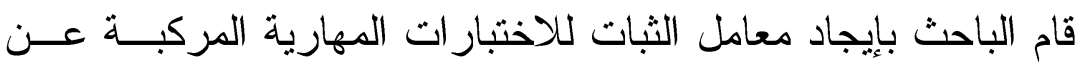

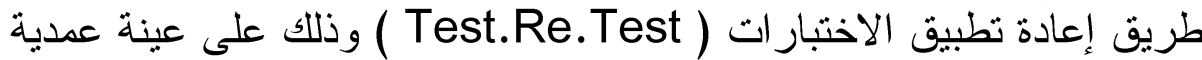

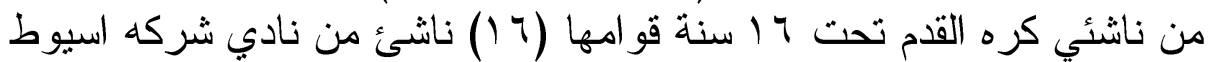

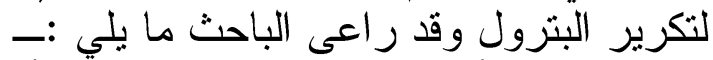

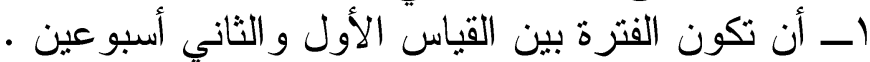

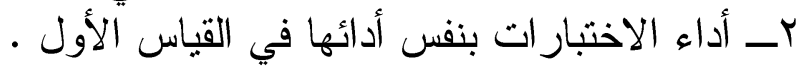


بــ استخدام نفس الأسلوب في القياس الأول .

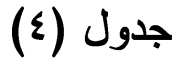

معامل الثبات لمتوسط زمن أداء اختبارات الأداء المهاري المركب قيد البحث (10= ن)

\begin{tabular}{|c|c|c|c|c|c|c|c|c|}
\hline \multirow{2}{*}{ معامل } & \multirow{2}{*}{ المتوسطات } & \multicolumn{2}{|c|}{ التطبيق الثاني } & \multicolumn{2}{|c|}{ التطبيق الاول } & \multirow{2}{*}{ القياس } & \multirow{2}{*}{ الاختبـــار ات } & \\
\hline & & $\varepsilon^{ \pm}$ & س & $\varepsilon^{ \pm}$ & س & & & \\
\hline.$\wedge 1 \mathrm{~V}$ &. $.1 r$ & سr. & 0.0 & $\cdot . \leqslant 1$ & $0.7 r$ & $\dot{H}$ & الاستلام ثم التمرير & 1 \\
\hline.$\vee \vee \wedge$ & $\because \wedge$ & .10 & V.ro &. & $V . \varepsilon r$ & $\dot{ث}$ & |لاستخام ثم الجري بــالكره & $r$ \\
\hline .VYr & 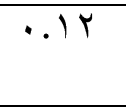 &.$r \wedge$ & 1.09 & o & A.VI & $\dot{H}$ & 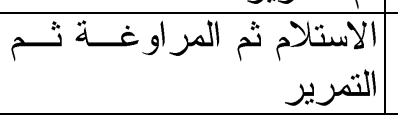 & r \\
\hline $.70 Y$ &. .07 & ו & $11 . \pi 1$ & M & $11 . \lambda \mathrm{V}$ & $\dot{H}$ & جرى بالكرهم و التمرير اوغــة ثــم & $\varepsilon$ \\
\hline .107 & $\cdots \varepsilon$ & $.1 \mathrm{~V}$ & E.YA &.$\mu \Lambda$ & E.rY & ث & الاستلام ثم التصويب . & 0 \\
\hline
\end{tabular}

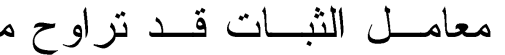

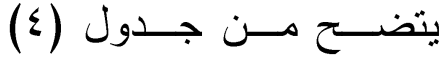

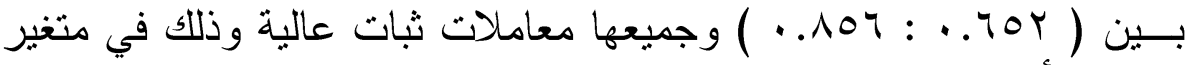

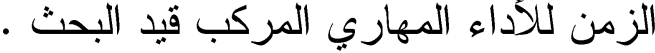

جدول (0)

معامل الثبات لمتوسط دقة أداء اختبارات الأداء المهاري المركب قيد البحث (ه) (10 = ن

\begin{tabular}{|c|c|c|c|c|c|c|c|c|}
\hline \multirow{2}{*}{ الثبات } & \multirow[t]{2}{*}{ المتوسطات } & \multicolumn{2}{|c|}{ التطبيق الثاني } & \multicolumn{2}{|c|}{ التطبيق الأول } & \multirow{2}{*}{ القياس } & \multirow{2}{*}{ الاختبـــار ات } & \multirow{2}{*}{ r } \\
\hline & & $\varepsilon^{ \pm}$ & س & $\varepsilon^{ \pm}$ & س & & & \\
\hline .190 &. YY &.$V Y$ & $1.7 \mathrm{~V}$ &.$v$. & 1.94 & درجة & الاستلام ثم التمرير • & 1 \\
\hline . Аঙی &.$r$. & $. v \leqslant$ & 1.04 &.$v \cdot$ & l.Vr & درجة & التمرير. ثم ثم الجري بالكره ثــم & r \\
\hline . & $\cdot r$. & $.7 r$ & $1.7 \mathrm{~V}$ &.$V \varepsilon$ & $1 . A V$ & درجة & 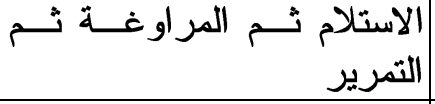 & r \\
\hline . Ar &.$Y^{\prime}$ &.$V Y$ & $1.7 \mathrm{~V}$ &.$\wedge$. & 1.94 & درجة & 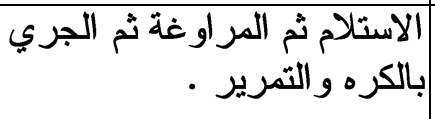 & $\xi$ \\
\hline
\end{tabular}




\begin{tabular}{|c|c|c|c|c|c|c|c|}
\hline $.7 \leqslant 0$ &.$r$. & . $\leqslant 7$ & $1 . K V$ & $.0 Y$ & $1 . \leqslant V$ & درجة & [الاستلام ثُم التصويب . \\
\hline
\end{tabular}

يتضح من جدول (0) أن معامل الثبات قد تراوح ما بين (

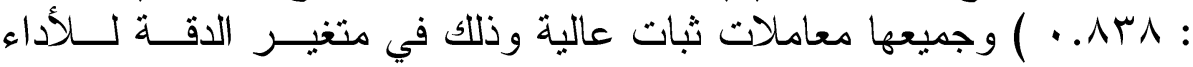

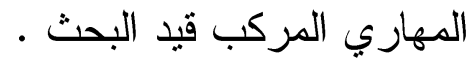

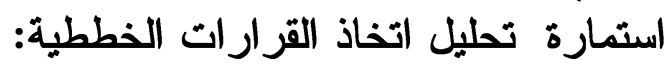
صدق المحتوى : لاستمارة تحليل اتخاذ القرارات الخططية المرتبطة قيداذ

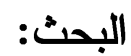
تم استخدام صدق المحتوى أو (المضمون) وذلك باستطلاع رأي الخبراء و المتخصصين في مجال كرة القدم حول محتويات استمارة و استمارة تحليل

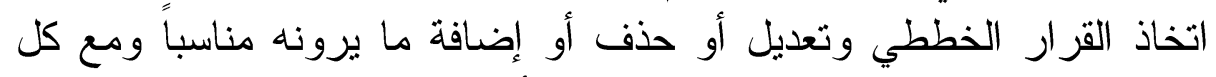

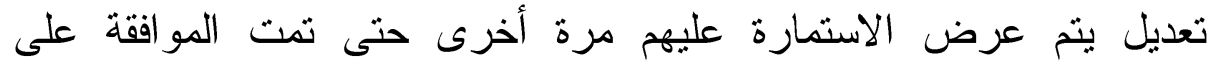

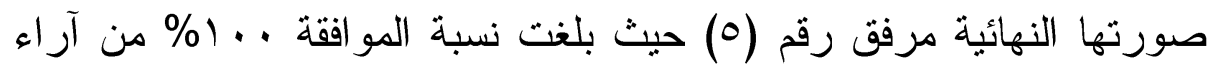

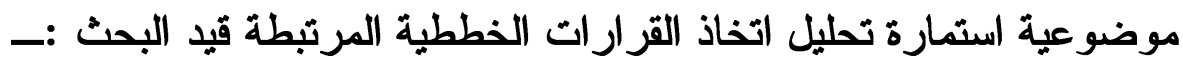
قام الباحث بتصوير مبار اة من خارج عينة البحث ومن مجتمع البحث لفريقين

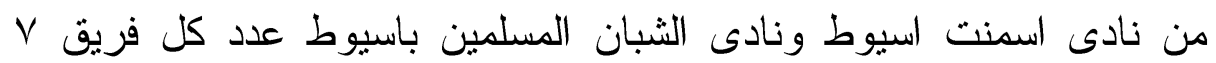

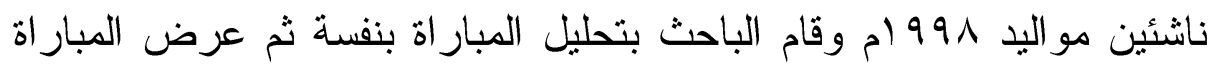

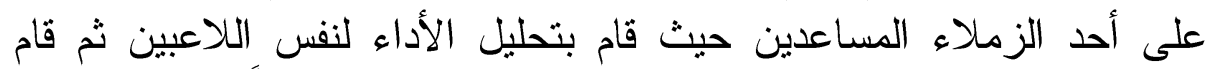

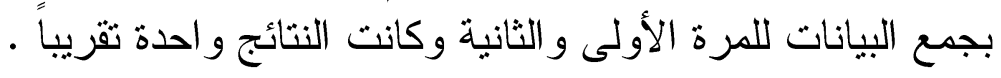
توصيف عينة البحث فى المتغيرات الاساسية:-

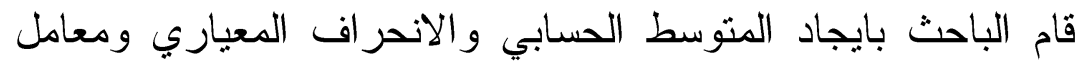
الا لتواء للمجموعه قيد البحث لايجاد التجانس بين افراد العينه في الاداء

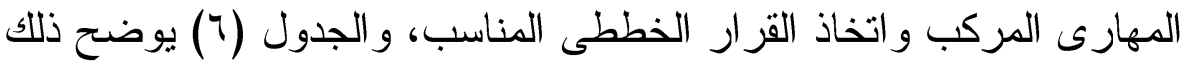


جدول(T)

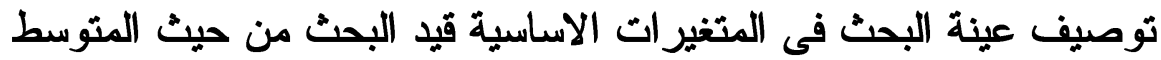

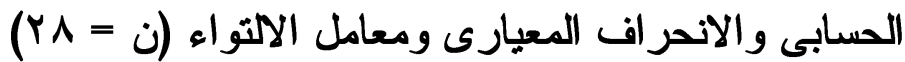

\begin{tabular}{|c|c|c|c|c|c|c|c|}
\hline الالثوء معامل & الانحر اف المعيارى & المستوسط & الاختبار ات & وحدة القياس & \multicolumn{2}{|c|}{ المتغير ات } & s \\
\hline 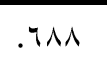 & $. V r) \cdot r$ & $1.7 \leqslant r q$ & الاستلام ثم التمرير • & $ث$ & المهارة (1) & \multirow{5}{*}{$\begin{array}{l}\bar{\lambda} \\
\bar{a} \\
\bar{y} \\
\bar{j} \\
y \\
\bar{y} \\
\bar{y} .\end{array}$} & $1 T$ \\
\hline $1 . .19$ & $. V \leqslant \varepsilon \leqslant V$ & I.orov & الاستلام ثم الجري & $ث$ & المهارة (ץ) & & $1 \varepsilon$ \\
\hline.$\varepsilon \cdot V$ & $. T Y 1 \leqslant \Lambda$ & $1.7 \leq r q$ & ثم الاستّلام ثم المراوغة & $ث$ & المهارة (ץ+) & & 10 \\
\hline .799 & .TAOYY & $1.7 \cdot 81$ & الاستريلام ثم المراوغة ثالكره والتمرير & $ث$ & المهارة (ع ) & & 17 \\
\hline $1 . . r$ & $. \leqslant 7 \ldots \leqslant$ & I. YAOV & الاستلام ثم التصويب . & 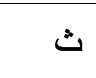 & المهارة (0) & & iv \\
\hline $.0 \ldots$ & $r . \varepsilon \| r$ & $r \mid . \leqslant T \leqslant r$ & المبــــــــــــاريات & عدد & منجاسب الخططى & اتخاذ & 11 \\
\hline
\end{tabular}

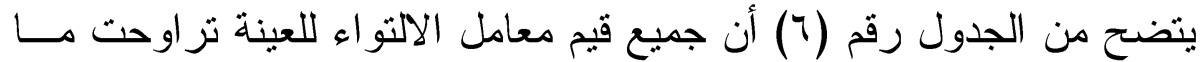

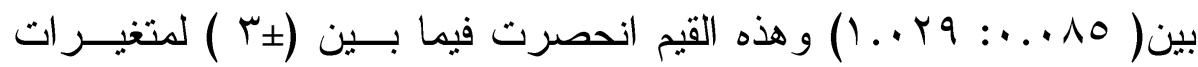

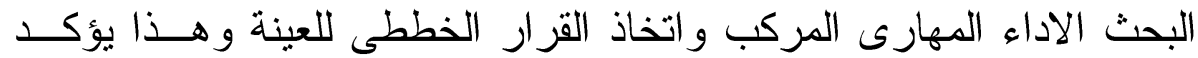

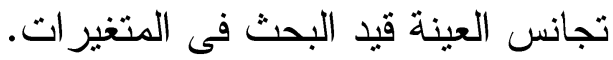

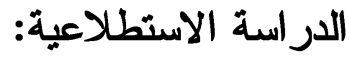

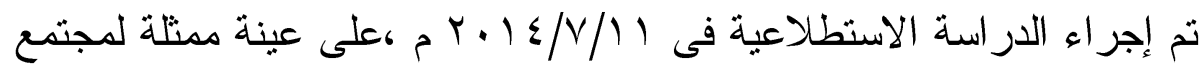

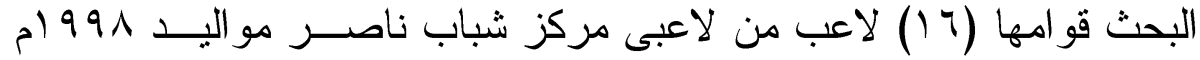
خارج عينة البحث الأساسية. وتهدف ثلك الدر اسه الى:

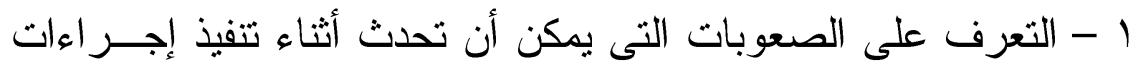
البحث الأساسية و العمل على حلها وتلافى حدوثها.

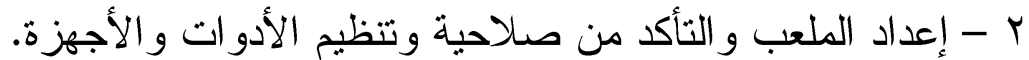


ب- إجر اء تطبيق الاختبار ات ومر اجعة شروطها.

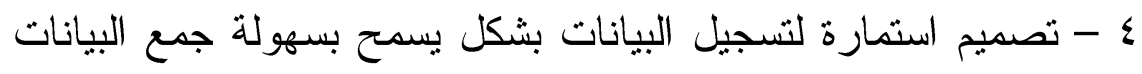
بصورة سهلة. 0 - تدريب المساعدين على تطبيق الاختبار ات بالطريقة العلمية المقننة.

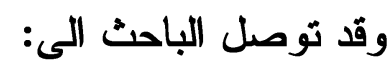
1- صلاحية الأدوات و الأجهزة المستخدمة في البحث.

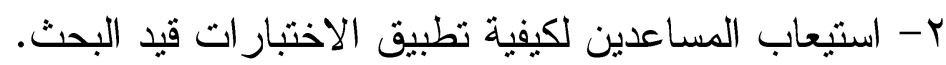
r- استيعاب المساعدين لطرق قياس الاختبار ات وتدوين النتائج.

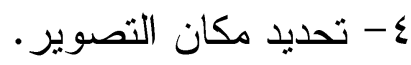

التدريبات المهاريه المقترحه :

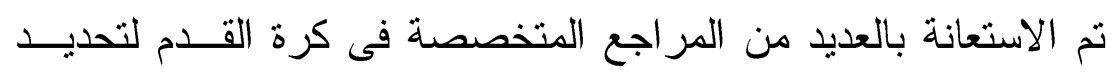

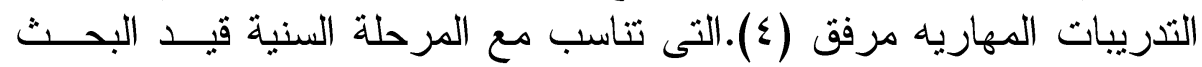

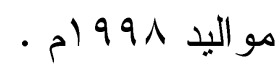
خطوات إعداد التدريبات المقترحه: قام الباحث بوضع التدريبات الخاصة بالأداء المهارى المركبه وذب و اتخاذ

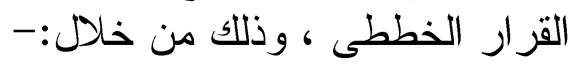

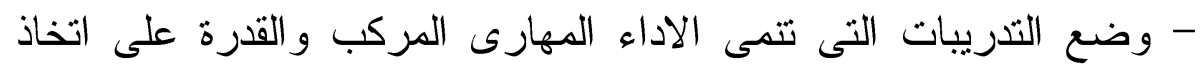

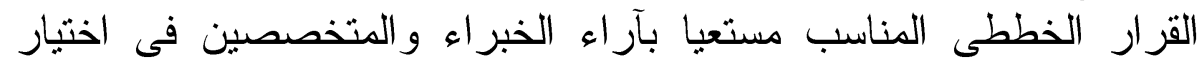
انسب تلك التدريبات حتى يكون تأثير ها ايجابيا على متغيرات ات البحث (مهارية

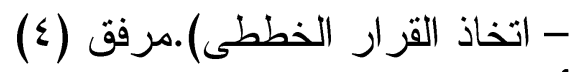
أهداف التدريبات المقترحه: تهذف التدريبات المقترحه إلى تتمية المهار ات المركبة واتخاذ القرار الخططى لناشئ كرة القدم تحت 7 اسنة في محاولة للوصول لأفضل مستوى خطوات تطبيق البحث:

قام الباحث بتطبيق التدريبات المقترحة (علي العينة الأساسية للبحث)

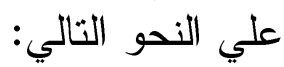
إجراء القياسات القبلية: 


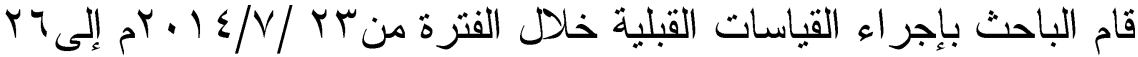

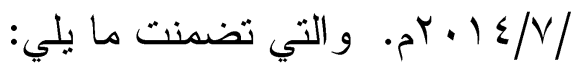

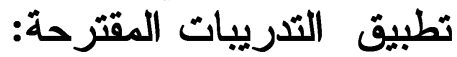

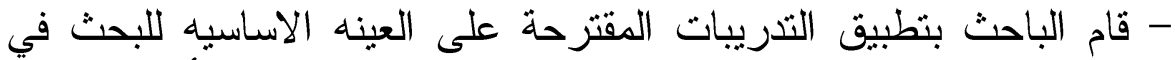

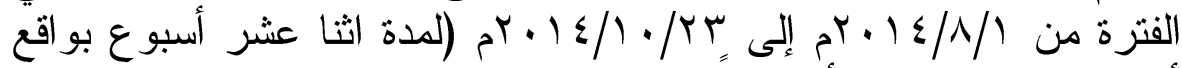

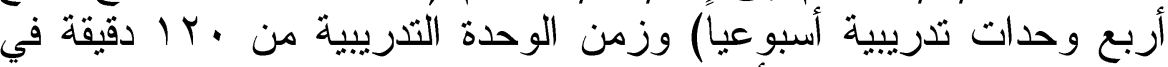

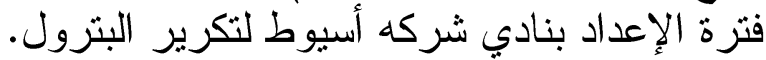
إجراء القياسات البعدية:

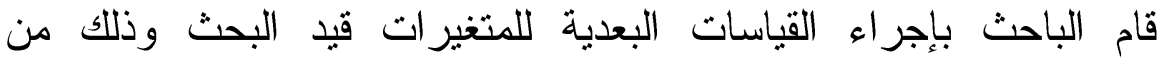

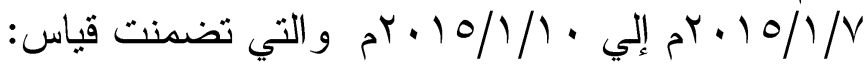
المعالجات الإحصائية المستخدمة: المان/

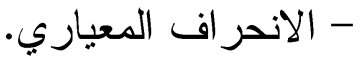

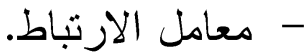

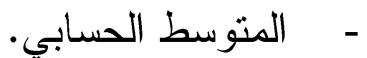

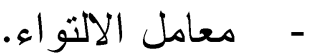
- - اختبار دلالة الفروق بين المتوسطات ( اختبار ت - T.test).

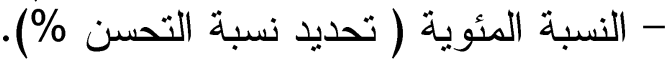
جدول (V)

عرض النتائج وتفسير ها:

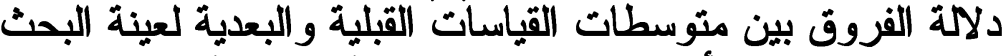

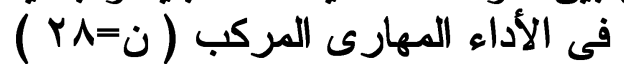

\begin{tabular}{|c|c|c|c|c|c|c|c|c|c|c|}
\hline \multirow{2}{*}{ الدالآئة } & \multirow{2}{*}{ المقيمة تبة } & \multirow{2}{*}{ التحسبة } & \multirow[t]{2}{*}{ المتوّروقطات } & \multicolumn{2}{|c|}{ القياس البعدى } & \multicolumn{2}{|c|}{ القياس القبلى } & \multirow{2}{*}{ الفياس } & \multirow{2}{*}{\multicolumn{2}{|c|}{ المتغير ات }} \\
\hline & & & & $\varepsilon \pm$ & س س & $\varepsilon \pm$ & س & & & \\
\hline دال & IY.rVA & $\% \backslash \wedge$ & $1 . .1$ &.$\leqslant Y$ & $\{.01$ &.$\varepsilon$. & 0.09 & $\dot{ث}$ & زمن & الاستلام ثم \\
\hline دال & 11.179 & $\% 111$ & $1 . \wedge Y$ & .01 & T.乏T &.$V \mu$ & $1.7 \varepsilon$ & درجه & دقه & التمرير \\
\hline دال & 9.199 & $\% 1 \cdot .0$ &.$\vee \vee \wedge$ &.$\leqslant 1$ & 7.70 &. & $V . \leqslant r$ & $\dot{H}$ & زمن & الاستلام ث \\
\hline دال & IT.乏AV & $\% \vee \varepsilon$ & $1.1 \leq$ &.$V V$ & T.TA &.$V \varepsilon$ & $1.0 \leqslant$ & درجه & دقة & التالكره ثي \\
\hline دال & $9.91 \leq$ & $\% \backslash 1$ & $.9 \mathrm{~V}$ &.$\leqslant Y$ & V.Vo & .ro & $\Lambda . V Y$ & $\dot{H}$ & زمن & الاستلام ثم \\
\hline دال & IY.A^O & $\% \leqslant 0 . \varepsilon$ & $1 . r r$ & .21 & T.AT & .74 & $1.7 \varepsilon$ & درجه & دقة & ثم التمرير \\
\hline دال & $Y . \leqslant \leqslant 0$ & $\% 7$ &. .79 & .04 & 11.17 &.$r$. & 11.10 & $\dot{H}$ & زمن & الاستلام ثم \\
\hline دال & $11.9 \ldots$ & $\% 7$. & .99 & .0. & Y.OV & .79 & 1.71 & درجة & دقة & 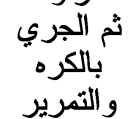 \\
\hline دال & $Y .000$ & $\% r$. & 1.19 &.$\wedge r$ & r... &.$r q$ & $\varepsilon . \mu r$ & $\ddot{v}$ & زمن & الاستلام ثم \\
\hline
\end{tabular}




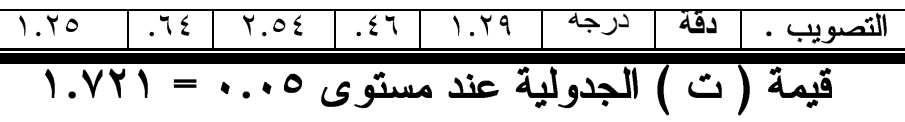

يتضح من جدول (V) وجود فروق دالة إحصــائيا بــين مثوســـات

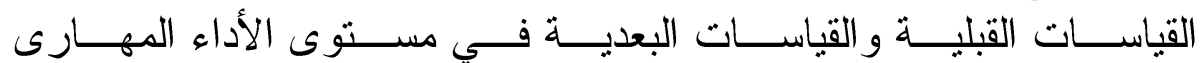
المركب(الاستلام ثم التمرير - الاستلام ثم الجرى بـالكرة ثــ التمريـر الاستلام ثم المراوغة ثم التمرير - الاستلام ثم المراوغة ثم الجرى بالكرة ثم التمرير - الاستلام ثم التصويب) للمجمو عة التجريبية لصالح القياسات البعدية

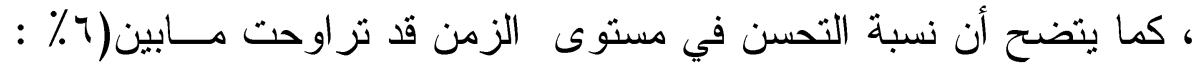

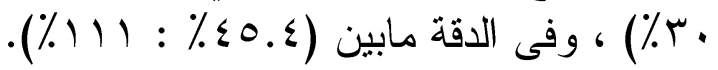

\section{جدول (^)}

دلالة الفروق بين متوسطاث القياساث القبلية و البعدية لعينة البحث

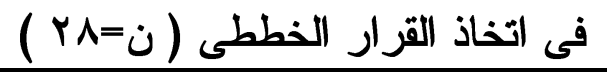

\begin{tabular}{|c|c|c|c|c|c|c|c|c|c|}
\hline \multirow{2}{*}{ الدلالة } & \multirow{2}{*}{ قالمسة ت } & \multirow{2}{*}{ التحسبة } & \multirow{2}{*}{ المثوسطات } & \multicolumn{2}{|c|}{ القياس البعدى } & \multicolumn{2}{|c|}{ القياس القبلى } & \multirow{2}{*}{ والقياس } & \multirow{2}{*}{ المتغير ات } \\
\hline & & & & $\varepsilon^{ \pm}$ & س & $\varepsilon^{ \pm}$ & س & & \\
\hline دال & 19.941 & $\% \vee q .4)$ & IV & $r . \wedge 1$ & rᄉ. $\leqslant T$ & r. $\leqslant 1$ & T). $\leqslant 7$ & عدد & الخطّار الخُاد \\
\hline
\end{tabular}

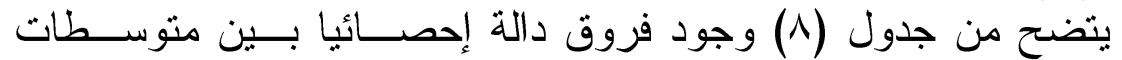

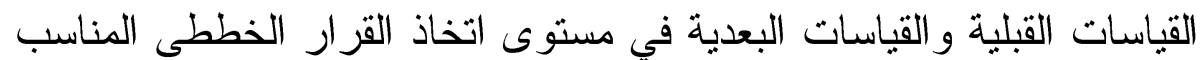

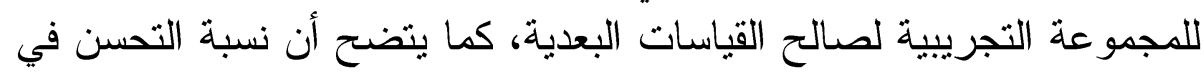

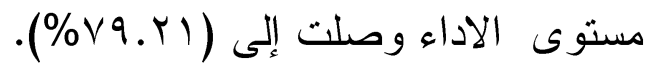




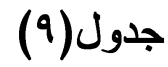

معامل الارتباط بين الاداء المهارى المركب واتخاذ القرار الخططى (ن= (Y)

\begin{tabular}{|c|c|c|c|c|c|c|}
\hline مستوى الدلالة & قيمة(ر) & الانحراف & الحتوسط & المتفيرات & & 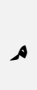 \\
\hline غير دال & $\cdot . \cdot 1$ &. .01 & r. $\{T$ & الاستلاه ثم التمرير & \multirow{5}{*}{ 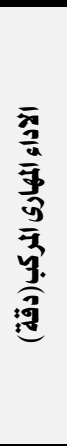 } & 1 \\
\hline غير دال &..$\Lambda$ &.$V Y$ & Y.TA & التمبرير. الاسم الجري بالكره ثم & & r \\
\hline غير دال &. .0 & $\cdot v 1$ & Y.人T & الاستلام ثم المراوغة ثم التمرير & & r \\
\hline غير دال &. .1 & .0 & Y.OV & بالكرهوالتمرير ثمر المراوغة ثم الجري & & $\varepsilon$ \\
\hline غير دال & מ & $.7 \leqslant$ & r.o & الاستلاه ثم التصويب & & 0 \\
\hline غير دال & $\cdots \varepsilon$ &..$\leqslant Y$ & $\varepsilon .01$ & الاستلاه ثم التمرير & \multirow{5}{*}{$\begin{array}{l}\frac{\overline{7}}{\frac{7}{a}} \\
\frac{5}{3} \\
\frac{3}{3} \\
\frac{7}{3} \\
\frac{3}{3}\end{array}$} & 1 \\
\hline غير دال &. $.1 \mathrm{~V}$ & $\cdot . \leqslant 1$ & 7.70 & الاستلام ثم الجري بالكره ثم & & r \\
\hline غير دال & $\cdot r_{1}$ & $\cdot . \leqslant Y$ & $\vee . V \varepsilon$ & الاستلام ثثم المراوغة ثم التمرير & & r \\
\hline غير دال & .1 & $.0 r$ & 11.17 & بالكرهوالتمرير ثم المراوغة ثم الجري & & $\varepsilon$ \\
\hline غير دال &. .99 & 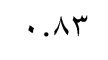 & r.. & الاستلاه ثم التصويب & & 0 \\
\hline
\end{tabular}

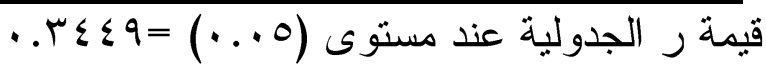
يتضح من جدول (9) عدم وجود ارتباط دال احصائياً بين كل من اتخاذ

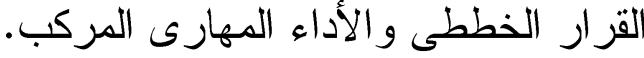

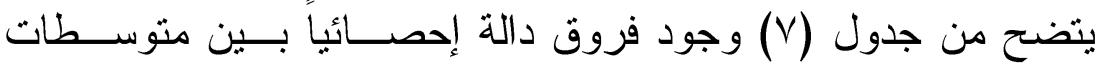

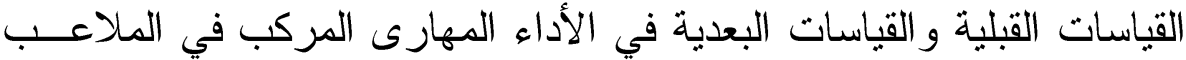

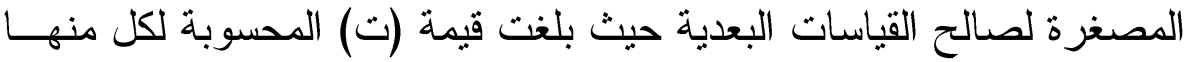

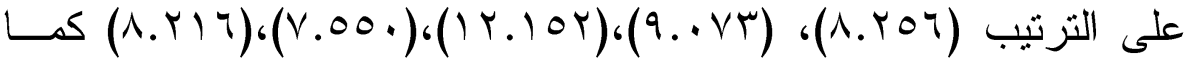

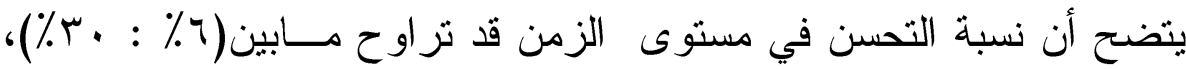




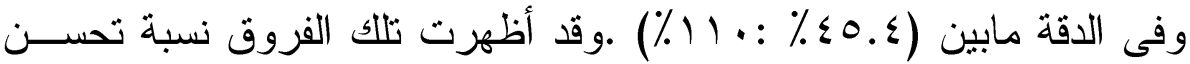

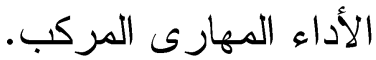

الاستلام ثم التمرير قد حقق أعلى نسبة تحسن في الدقة وقد يرجع الباحث

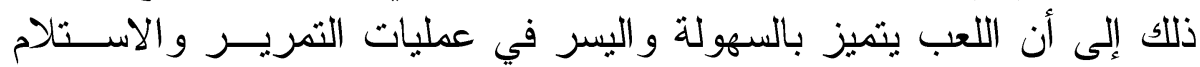

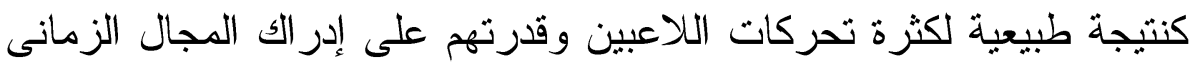

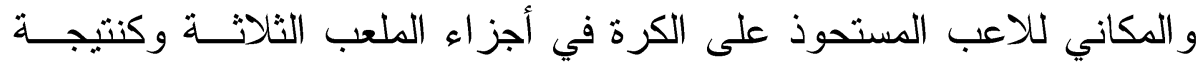

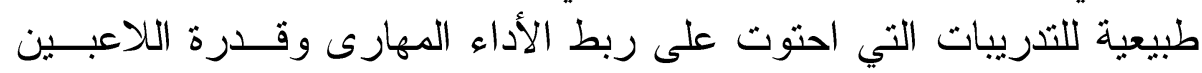

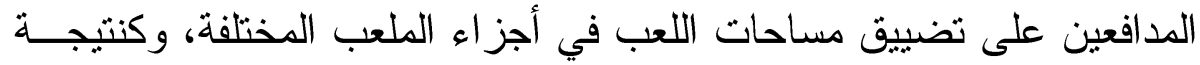

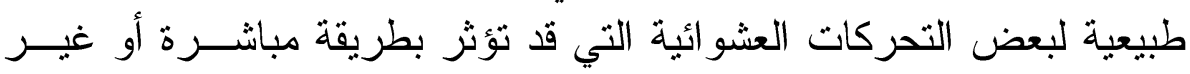

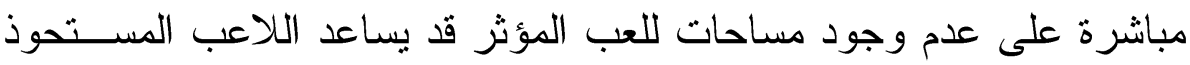

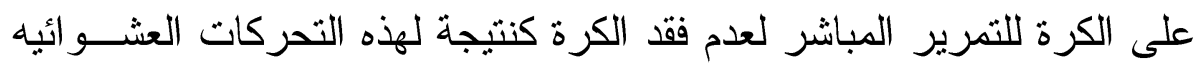
من المدافعين.

و هذا ما يؤكده مفتى إبر اهيم ( •99 ام) على أن تمرير الكرة من لمسة

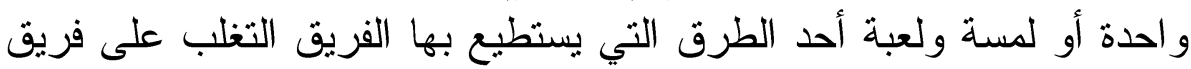

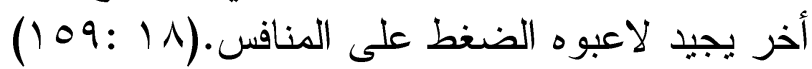

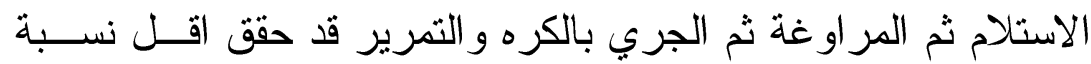

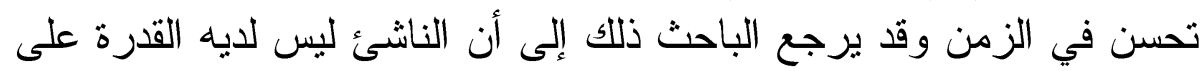

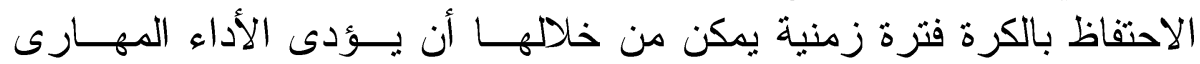

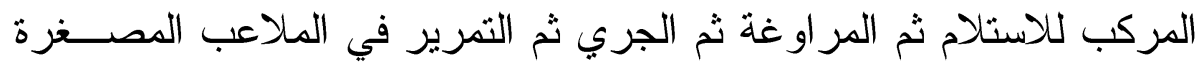

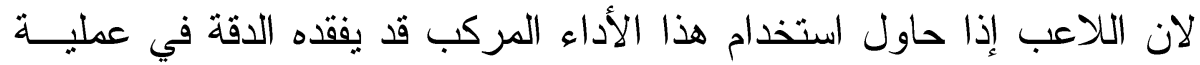

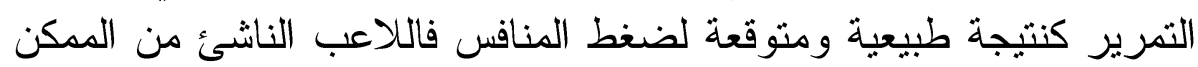

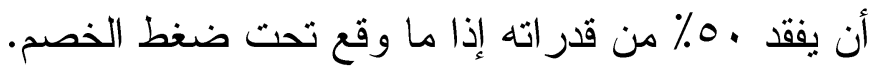

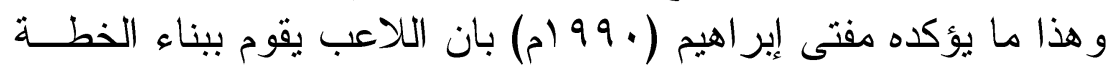

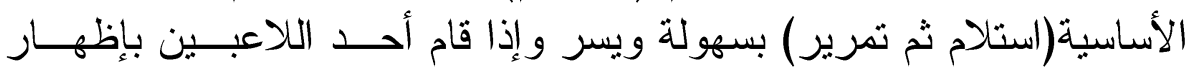

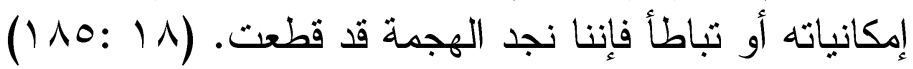

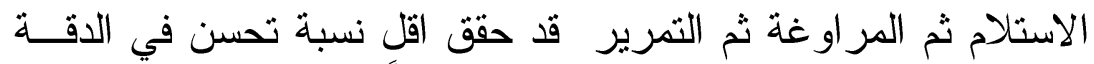

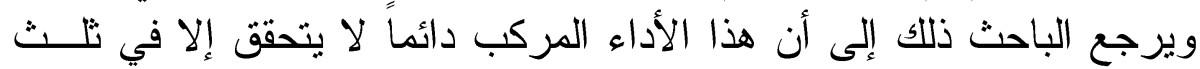

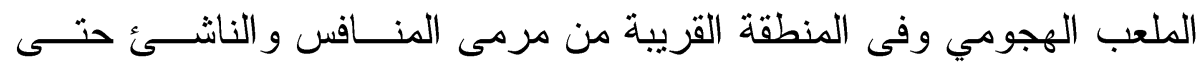




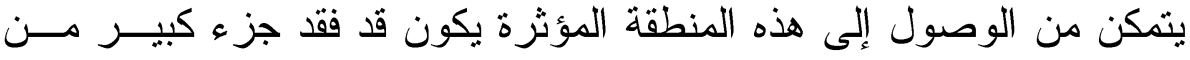

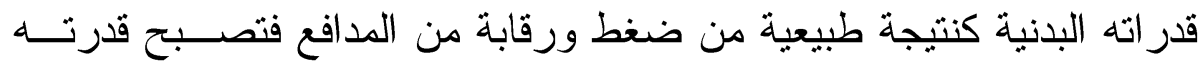
على تتفيذ التمرير غير دقيقة وغير مؤثرة.

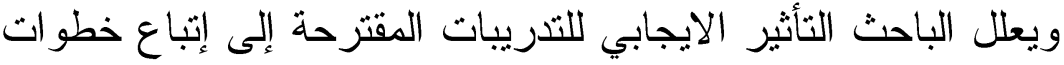
وتدريبات تؤدي إلى تحسن الأداء المهاري لكل لاعبي الفريق ولم يفرق بين

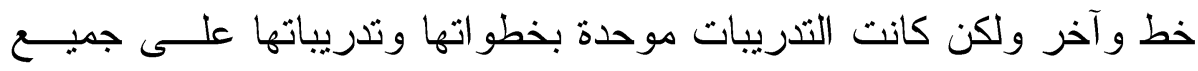

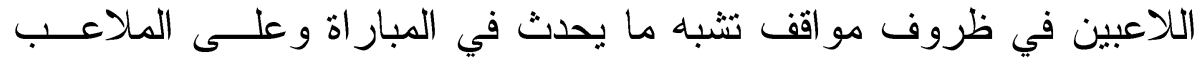

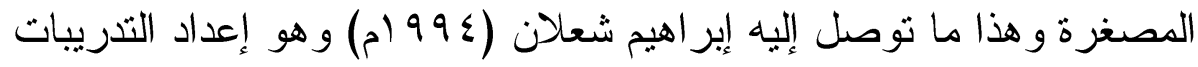

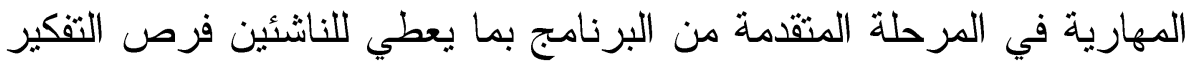
واتخاذ القرار و التي تتضمن مواقف اللعب المختلفة ومتطلبات الأداء خـــلاهل

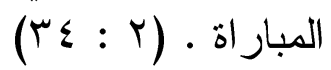

كذلك اهنمام التدريبات ببناء الهجوم بعد إفشال خطة الهجوم للفريق

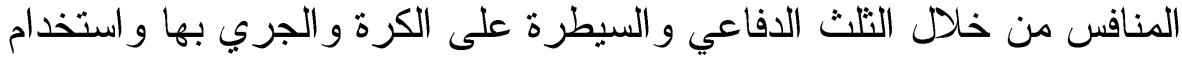

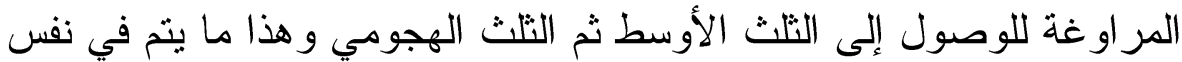
ظروف المبار اة وفى الملاعب المصغرة أثثاء استخدام التدريبات المهارية قي

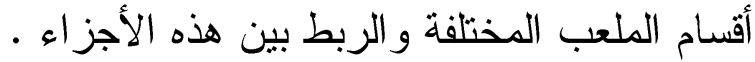

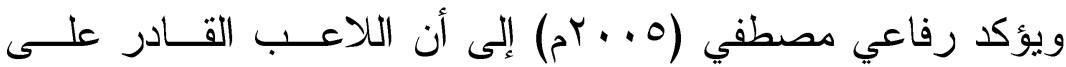

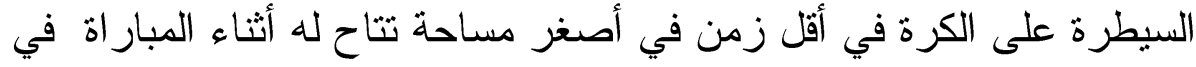

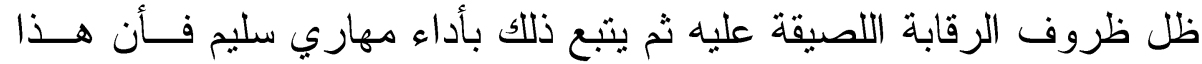

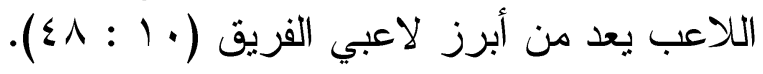

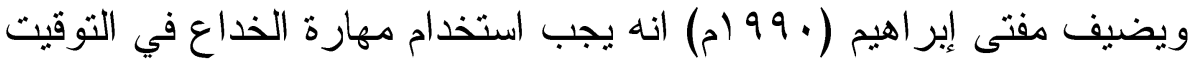
السليم و الموقف المناسب لاستخدامها حيث ان المغالاة في استخدامها بصورة

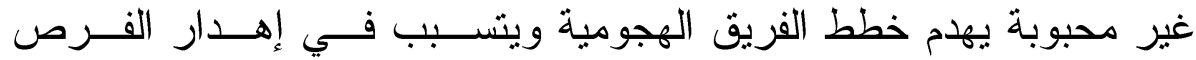

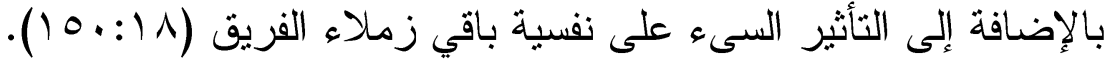

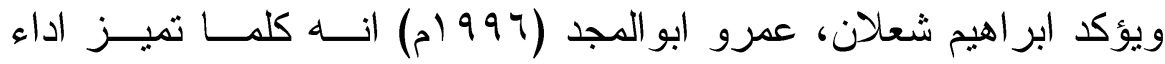

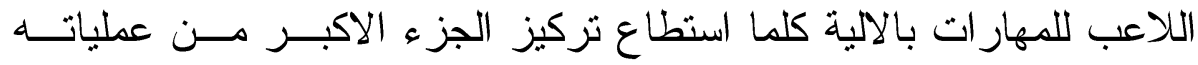

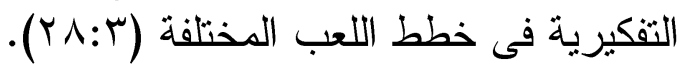


كما ساعدت التدريبات المهارية فى الملاعب المصغرة فى تحسن اســتخدام تمارين الجري المتعرج بالكرة وكذلك الوثب وتغيير الاتجاهات بسرعة مـــن فئن

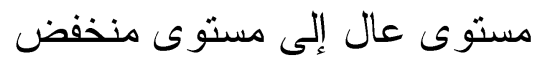

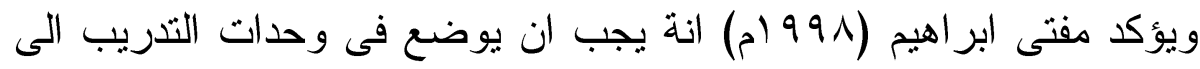

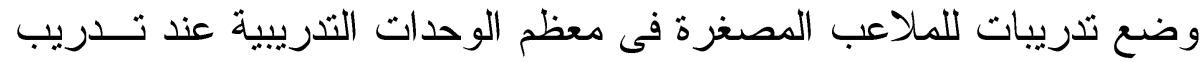

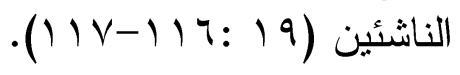

- الاستلام ثم التمرير قد حقق أعلى نسبة تحسن في الزمن ويرجع الباحث

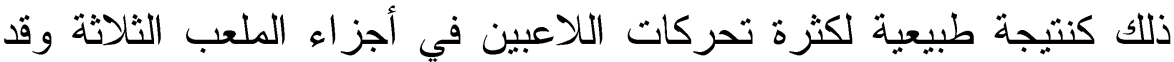
يظهر ذلك في عمليات البناء والتطوير والإنهاء وكنتيجة طبيعية للتدريبات

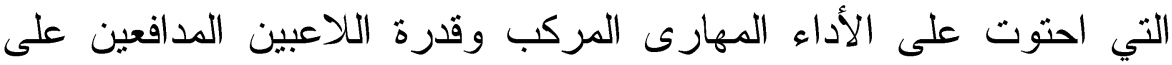

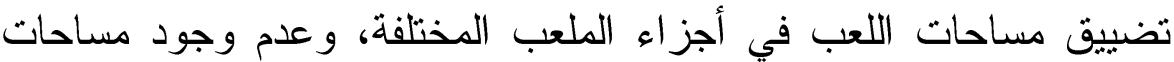

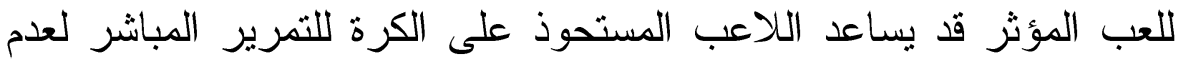
فقد الكرة كنتيجة لهذه التحركات العشو ائيه من المدافعين.

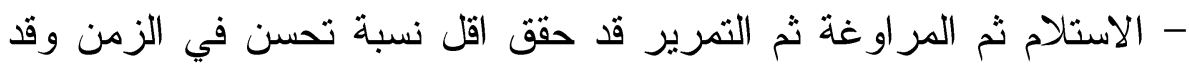
يرجع الباحث ذلك إلى أن الناشئ ليس لديه القدرة على الاحتفاظ بالكرة فترة

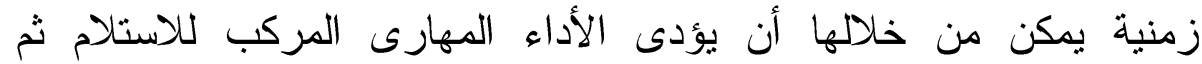
المراوغة ثم التمرير لان اللاعب إذا حاول استخدام الأداء المركب قد يفقده

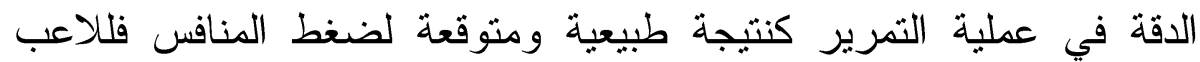

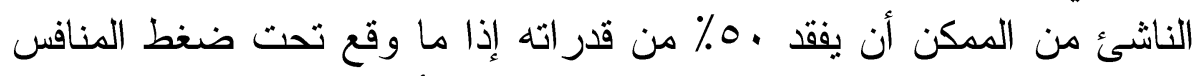

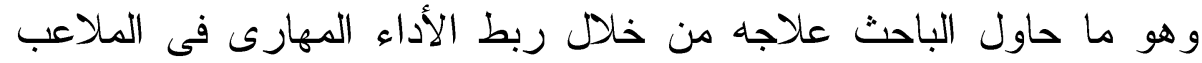
المصغره باتخاذ القرار الخططى.

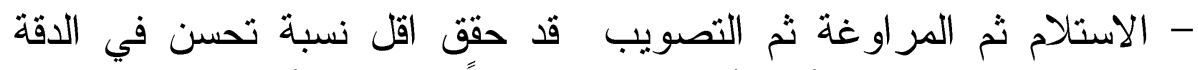

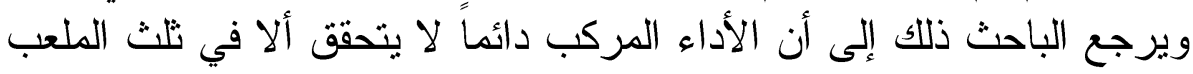

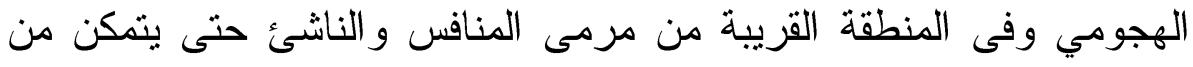
الوصول إلى هذه المنطقة المؤثرة يكون قد فقد جزء كبير من قدراته البدنية

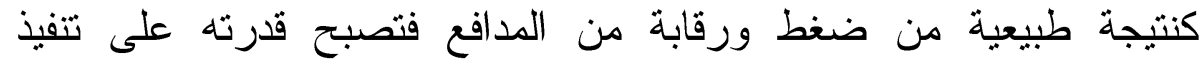
التصويب غير دقيقة وغير مؤثرة . 


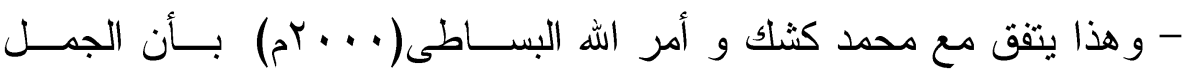

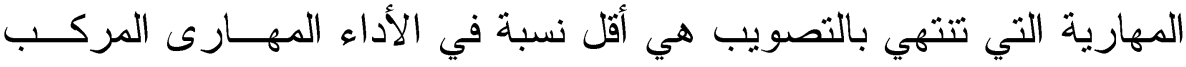

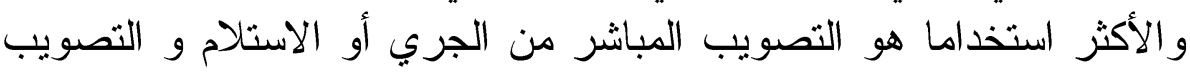

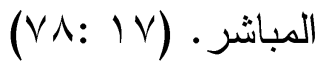
- ويرجع الباحث ذلك إلى وصول اللاعبين إلى مرحلة التبيــــ و الإتقــان

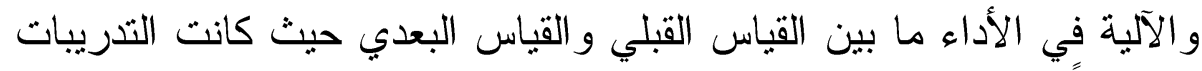
تثم دائما في صورة تدريبات تشبه ما يحدث في المبار اة ومتدرجة من السهل

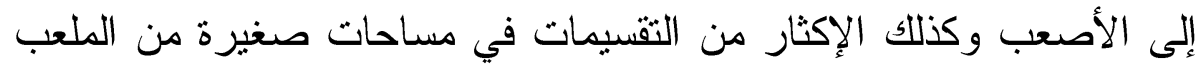

$$
\text { بوجود مدافع سلبي ثم إيجابي. }
$$

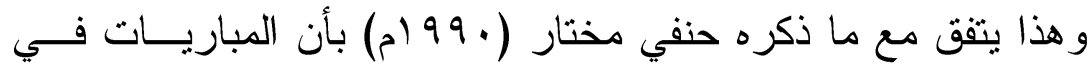

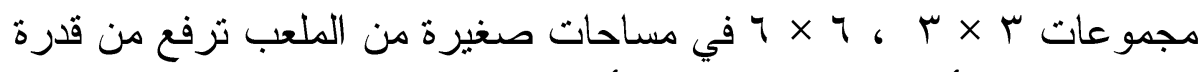

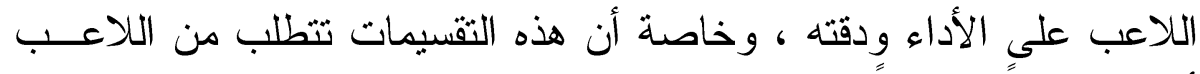

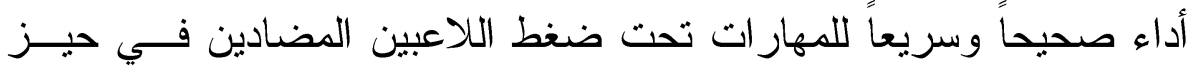

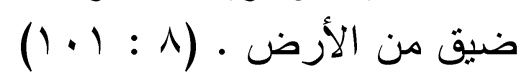

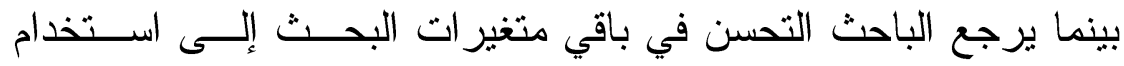

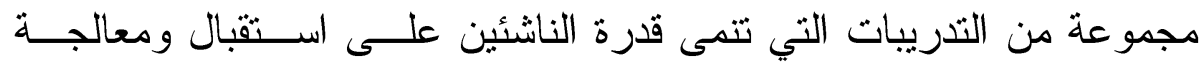

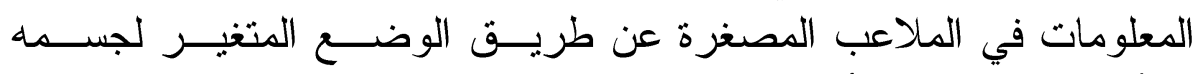

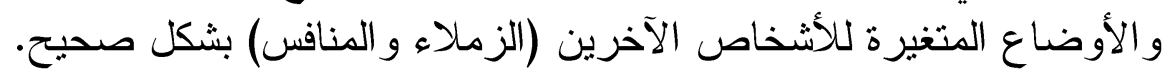

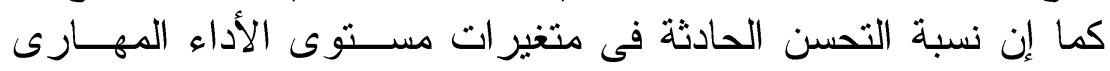

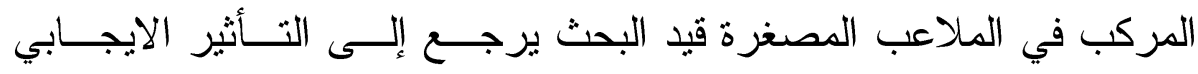

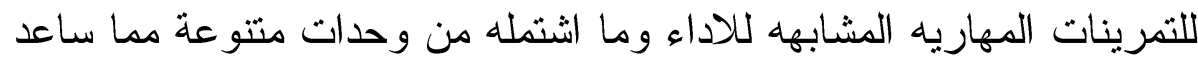

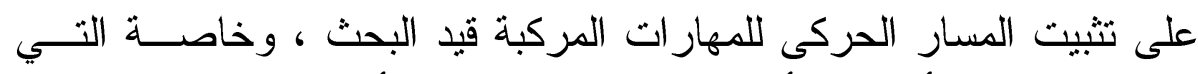

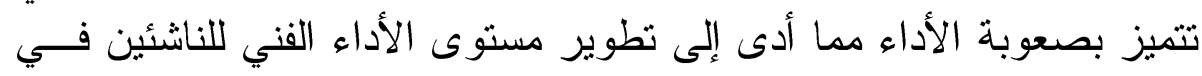
الملاعب المصغرة. وبذلك يتحقق الفرض الأول" توجد فروق ذات دلالة احصـــائية بــين

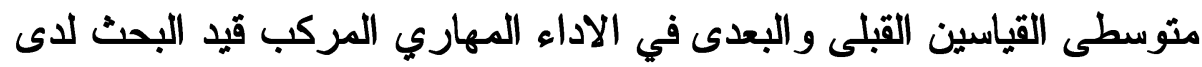
ناشئ كره القدم لصالح القياس البعدى. 
يتضح من جدول (9) وجود فروق دالة إحصائيا بـين متوســات

القياسات القبلية و القياسات البعدية في مستوى اتخاذ القرار الخططى المناسب

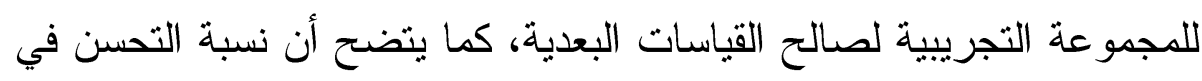

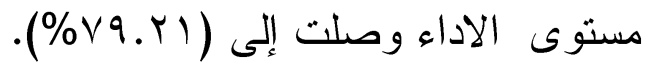

و يرجع الباحث سرعه اتخاذ القرار الخططي النظري و العملي للناشئين

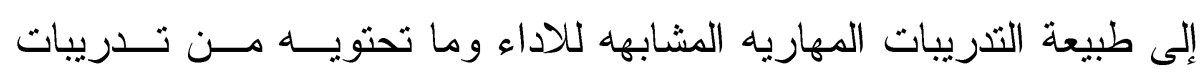

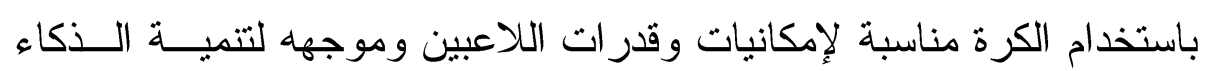

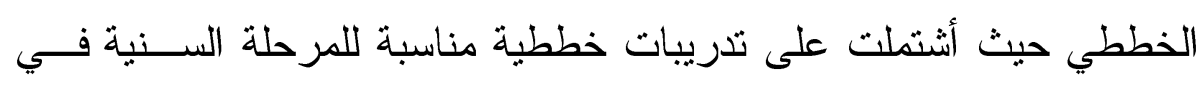

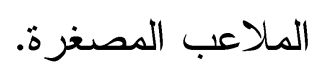

ويتضح من جدول (9) عدم وجود علاقة ارتباطيه بين كل من المتغيرات

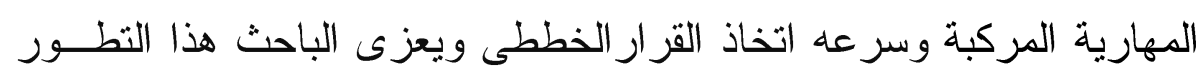

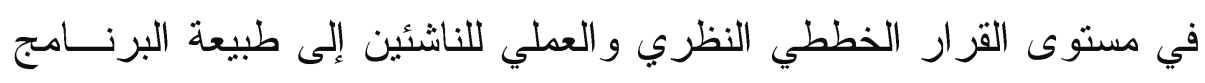

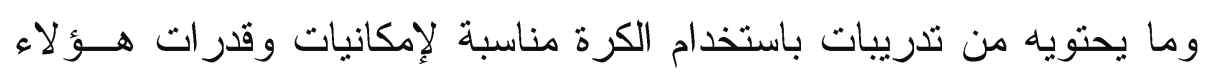

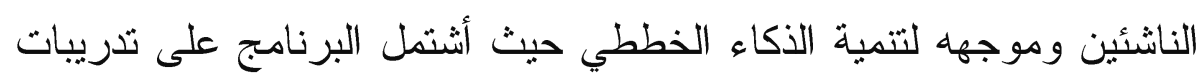

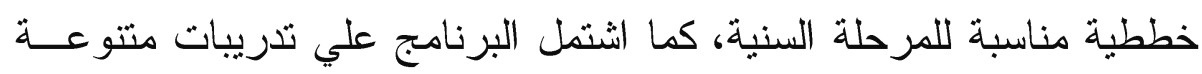
لتنمية اتخاذ القرار الخططي العملي للناشئين. مما سبق يري الباحث أن الناشئ الذكي أقدر من غيره بطبيعة الحـــال

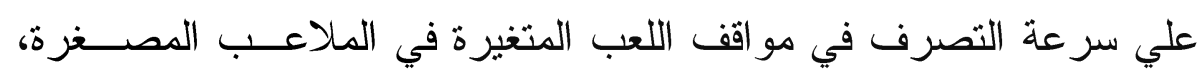

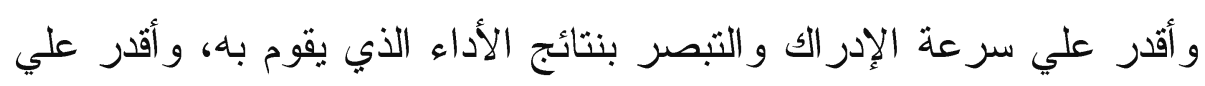
توقع سلوك المنافس في أثناء اللعب.

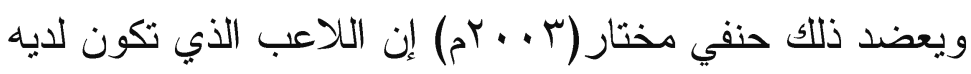

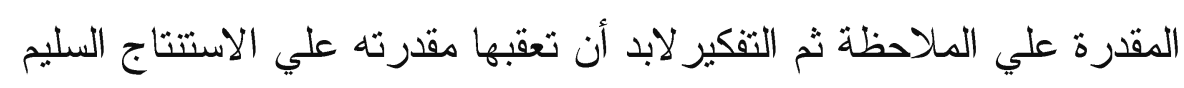


لما لاحظه حتى يتخذ القرار الصحيح فيما يجب عمله، و لأهمية هذه العملية

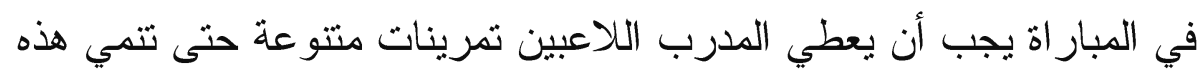

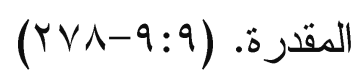

وعموماً فإن اللاعب المعد ذكاءه الخططي جيدا تكون سرعة تلبيته أسرع

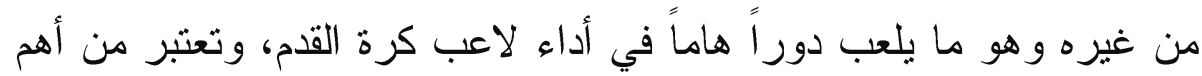

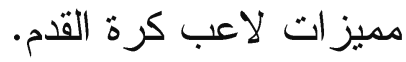

وبذلك لم يتحقق الفرض الثانى"توجد علاقة ارتباطية دالة احصائيا بين الاداء المهاري المركب قيد البحث وسرعه اتخاذ القرار الخططى لناشئ كره القدم".

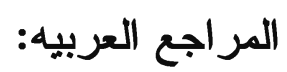

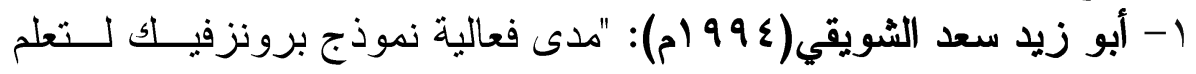

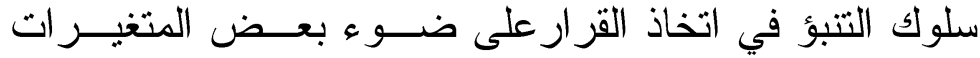
المعرفية و اللامعرفية"، رسالة دكتور اه، كلية التربية، جامعسـة التئة

$$
\text { طنطا. }
$$

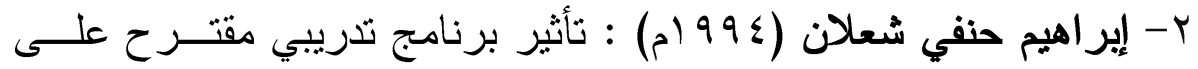

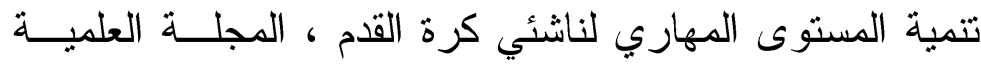

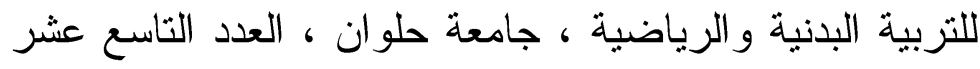

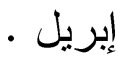

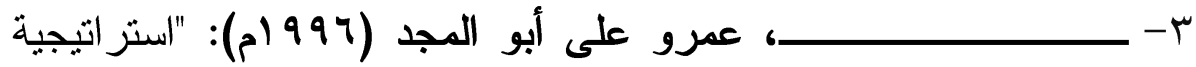

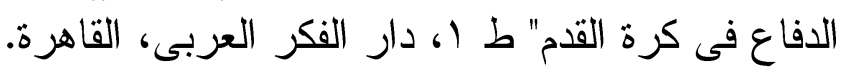

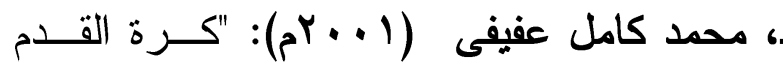

للناشئين" ط ا، مركز الكتاب للنشر ، القاهزة.

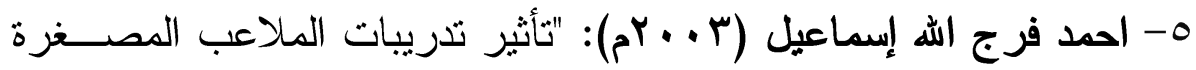

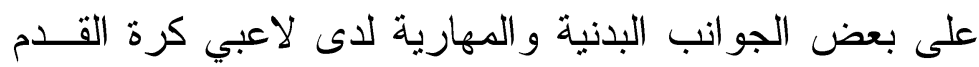

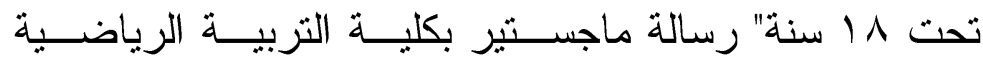
ل اللبنين،جامعة حلوان، القاهرة. 
؟- أمر الله احمد البساطى (990 (م) : التّريب و الإعداد البدني فى كـرة القدم، منشأة المعارف، الإسكندرية.

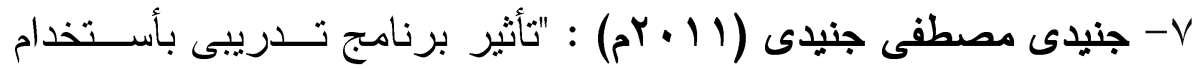

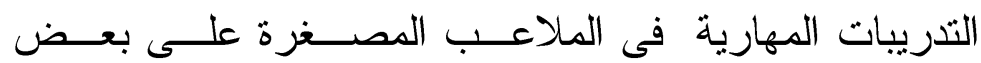

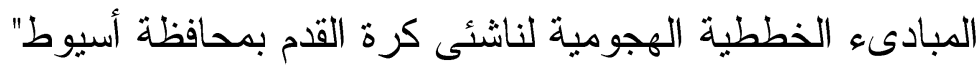

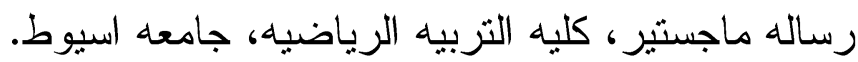

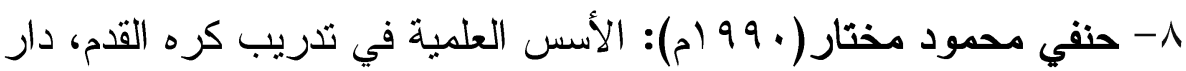
الفكر العربي ، القاهرة. 9- حنفي محمود مختار( •99 (م): "الأسس العلمية في تدريب كرة القدم"،

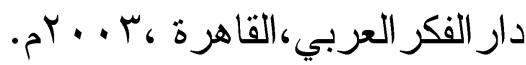
• 1- رفاعي مصطفي حسين (0. ․ . م) : " أصل تدريب كرة القدم" عــامر للطباعة و النشر . مبطرن

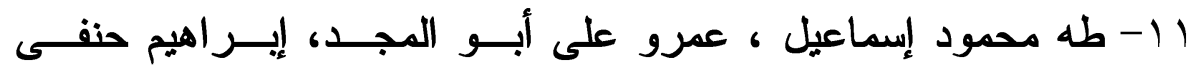

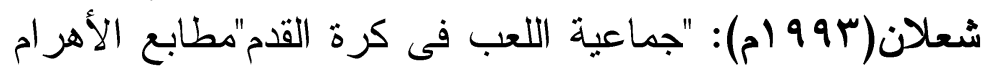
التجارية ، القاهرة.

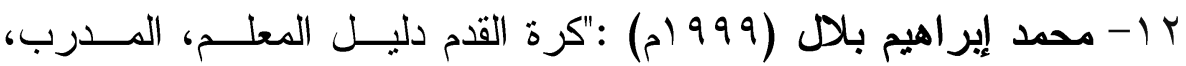

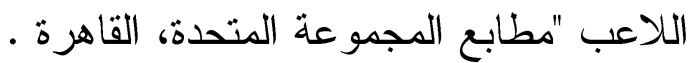

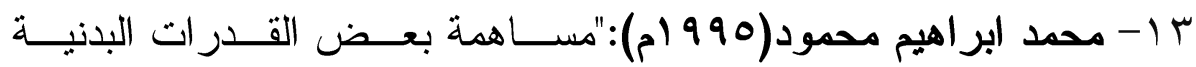

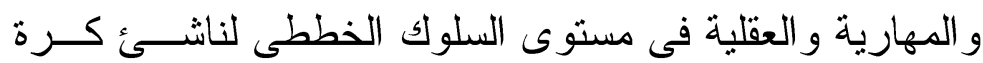

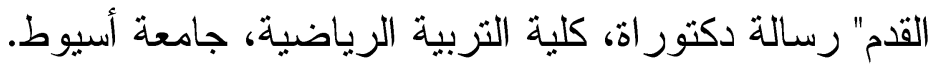

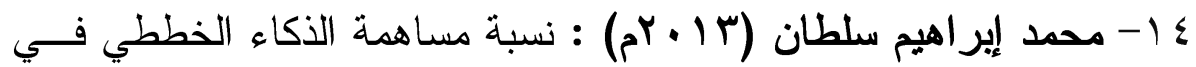

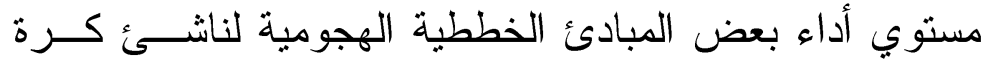

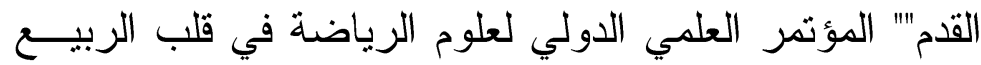

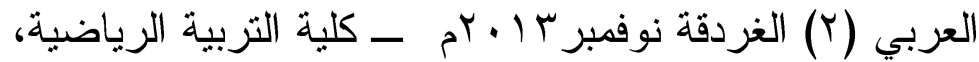
جامعة أسيوط.

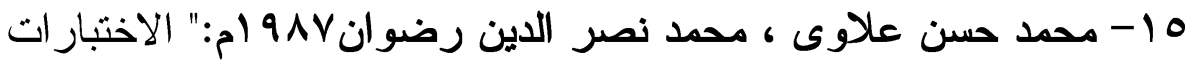

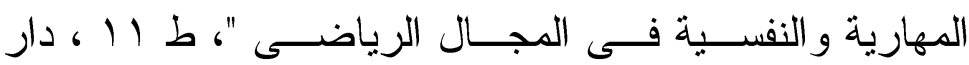
المعارف ، القاهرة. 


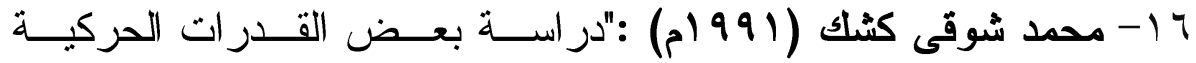

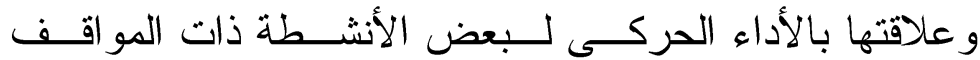

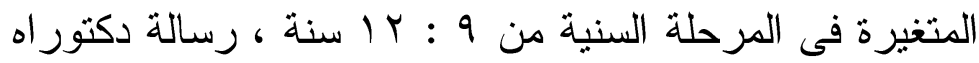

، كلية التربية الرياضية للبنين ، جامعة الإسكندرية.

IV - IV

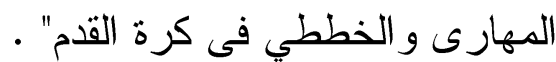

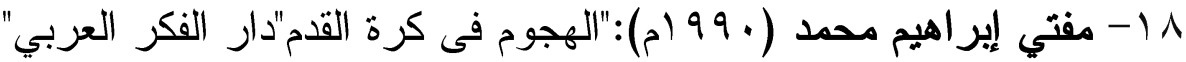

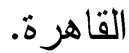

9 ا - مفتى إير اهيم محمد (99V (م ):البر امج التدريبية المخططة لفرق كرة

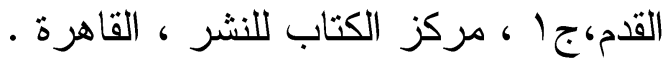

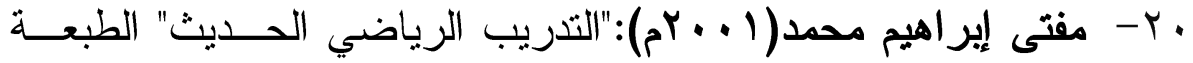
الثانية، دار الفكر العربي، القاهرة.

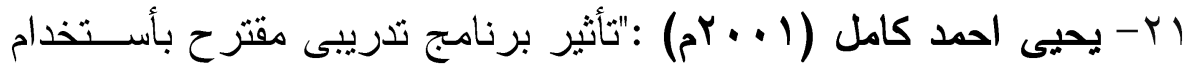

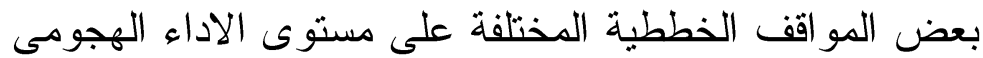

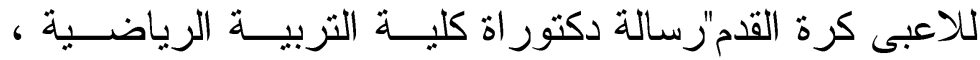

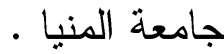

المر اجع الاجنبيه: - المعايه

22- Paul Calligiuri \& Dancers ( 1997 ): High performance soccer techniques and tactic for adranced play human kinetics

23- Terry Mc. Morris and Jan Graydon: the effect of exercise on the desionmorking performance of experienced and inexperienced soccor player research quortery of exercise of exercise and sport American and alliance for health. 1986.

24- www . strikers soccer. Com / princibles. Htm- 14k 2002.

25- www . 3v3 gales. Com / rnles. html 2009. 